\title{
BIOETHANOL PRODUCTION TECHNIQUES FROM LIGNOCELLULOSIC BIOMASS AS ALTERNATIVE FUEL: A REVIEW
}

\author{
Abdulfatah Abdu Yusuf *, Freddie L. Inambao \\ Discipline of Mechanical Engineering, University of KwaZulu-Natal, Durban, South Africa \\ *Corresponding Author
}

\begin{abstract}
Bioethanol production from lignocellulosic biomass (LCB) has been demonstrated as alternative to conventional fuel, as it is considered to be renewable and clean energy. The major problem of bioethanol is the availability of biomass materials for its production. This review paper aims to provide an overview of the recent developments and potential regarding production techniques, ethanol yields, and properties, as well as the effects of bioethanol fuel as replacement for fossil fuel. The literature indicates that the best results have been obtained with cellulase and $\beta$-glucanase cocktail which significantly increases bioethanol production compared to fermented acid pretreatment. The classification of pretreatment, hydrolysis, and fermentation have significant effects on physico-chemical properties of bioethanol fuel, which also influence the internal combustion engines. Difference in operating conditions and physico-chemical properties of bioethanol fuels, may change the combustion behaviors and sometimes makes it difficult to analyze the fundamentals of how it affects emissions.
\end{abstract}

Keywords: Bioethanol; lignocellulosic biomass; combustion behaviors; emissions.

Cite this Article: Abdulfatah Abdu Yusuf and Freddie L. Inambao, Bioethanol Production Techniques from Lignocellulosic Biomass as Alternative Fuel: A Review, International Journal of Advanced Research in Engineering and Technology, 10(3), 2019, pp 259-288.

http://iaeme.com/Home/issue/IJARET?Volume=10\&Issue $=3$

\section{INTRODUCTION}

Energy consumption associated with the transportation sector has contributed to a world problem. The world's energy demand is increasing every day and the problem of fossil fuel depletion is looming (Iodice \& Senatore, 2016). These challenges have led to new approaches focusing on energy consumption management and alternative fuel sources so as to increase efficiency and reduce greenhouse gas emissions respectively (Yusuf \& Inambao, 2018). Biomass is the most common form of a renewable primary energy resource that can provide alternative transportation fuels (McKendry, 2002; Sun \& Cheng, 2002). Biofuels are a variety of fuels which can be produced from agro-industrial waste, algae material or various lignocellulosic biomass (LCB) sources in many different ways (Calam, Içingür, Solmaz, \& 
Yamk, 2015). Among the various biofuels, bioethanol presents the most suitable renewable, bio-based and eco-friendly fuel for SI engines mainly because it has similar properties to gasoline in terms of high octane number, high flame speed, low stoichiometric air-fuel ratio and low heating value (Calam et al., 2015; Iliev, 2015; Zhen, 2018).

Thus, production of bioethanol from biomass is a process of decreasing the consumption of crude oil and reduce $\mathrm{CO}_{2}, \mathrm{NOx}$ and $\mathrm{SOx}$ emissions released into the atmosphere as a result of fossil fuel combustion (Thangavel, Momula, Gosala, \& Asvathanarayanan, 2016; Tibaquir \& Huertas, 2018). Many researches have been conducted on production of bioethanol from a simple conversion of various biomass sources such as sugarcane, corn, cassava, banana peels, rice straw and other agricultural waste by means of fermentation (P. Kumar, Barrett, Delwiche, \& Stroeve, 2009; Xu \& Huang, 2014), to the multi-stage conversion system of LCB into bioethanol (Binod et al., 2010; Sarkar, Ghosh, Bannerjee, \& Aikat, 2012). In this context, the utilization of various agricultural residues (such as wheat straw, rice straw, banana peel, sugarcane bagasse, rape straw, and corn stover) containing carbohydrates for the production of bioethanol have been reported. In Uganda, $91.4 \mathrm{~kg}$ per capita of Matooke (banana) peels are generated per year, a small portion of which is used for animal feeds, and briquettes while a large portion is left to waste away contributing to an increase in environmental residues. It is important to research the possible ways of adding value to these wastes, but production costs can vary widely considering conversion process, the scale of production, lignocellulosic material and region. The current research focused on the development of bioethanol through agro-industry waste that does not compete with the food chain, which is sustainable and efficient regarding both costs and energy. This review paper aims to give an overview of the recent studies on production techniques, ethanol yield, properties, and useful characteristics of bioethanol from LCB as replacement for fossil fuel. This will provide a benchmark for the development of biofuels from Matooke peels in Uganda.

\section{LIGNOCELLULOSIC BIOMASS COMPOSITION AND STRUCTURE}

LCB is an abundant, renewable source of carbohydrates for microbial conversion to chemicals and fuels (Geddes, Nieves, \& Ingram, 2011). It is derived from agricultural residues, such as straw, wood and other agricultural waste (Aditiya et al., 2016; Domínguez-Bocanegra, TorresMuñoz, \& López, 2015). This type of biomass can be converted into liquid fuel. This in turn improves the $\mathrm{CO}_{2}$ balance, and since it is a waste resource, it does not compete with human food chain (Soccol et al., 2010). The composition of LCB is categorized into three main parts: cellulose (30\% to $50 \%$ dry wt.), hemicellulose (20\% to $40 \%$ dry wt.) and lignin (10\% to 20 $\%$ dry wt.) (Limayem \& Ricke, 2012; Putro et al., 2015; Sebayang et al., 2016). The molecular structure of cellulose, hemicellulose, and lignin are shown in Fig. 1. 

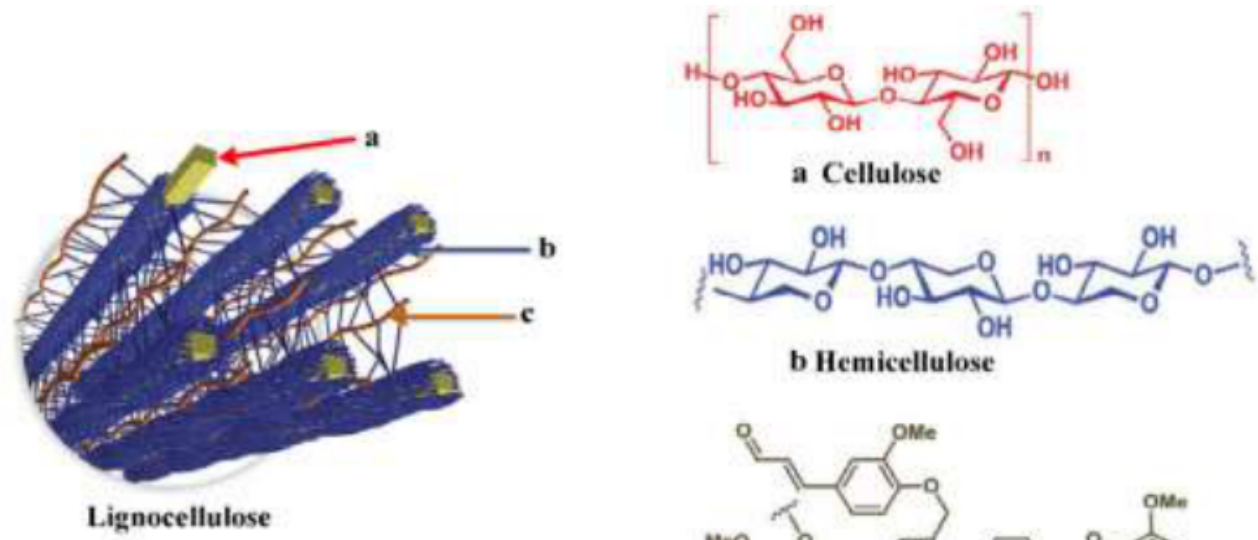

b Hemicellulose

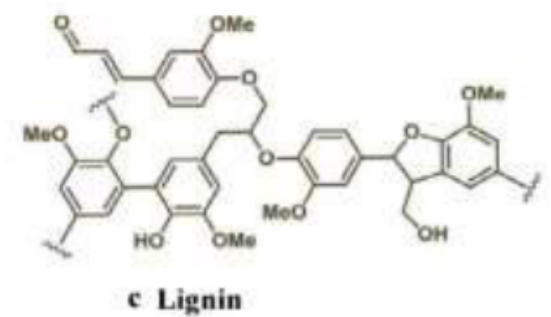

Figure 1 Lignocellulosic biomass (a) Cellulose; (b) Hemicellulose; (c) Lignin (Brandt, Gräsvik, Hallett, \& Welton, 2013; Kobayashi \& Fukuoka, 2013).

\subsection{Cellulose}

Cellulose (C6H10O5)n is a hexoses sugar from agricultural biomass and woody (Balat, 2011). It is a linear polymer of glucose monomers (D-glucose) linked to $\beta-(1,4)$-glycosidic bonds, and consists of a long chain of $\beta$-glucose monomers gathered into micro-fibril bundles (Ebringerová \& Thomas, 2005; Haghighi Mood et al., 2013). Cellulose is insoluble in water, and allow the hydrolysis process to break down the polysaccharide to free sugar molecules by increasing water content known as saccharification (Hamelinck, Van Hooijdonk, \& Faaij, 2005). Figures 2, 3 and 4 describe the schematic concepts of a biorefinery from LCB sources as the starting point for the production of a variety of molecules, and their application for fuels and biochemical platforms related to the agro-industry. Chemicals that can serve as a starting point for other chemicals are often called platform chemicals (Engdahl \& Tufvesson, 2012).

The overall hydrolysis of cellulose produces only glucose, which can be converted into different forms of biochemical substances and chemical (Fig. 2). Biological processes can lead to a wide range of substances such as bioethanol, organic acids, glycerol, sorbitol, mannitol, fructose, enzymes, and biopolymers. This is due to the existence of an exclusive and common metabolic pathway for the great majority of living beings (Päivi Mäki-Arvela, Salmi, Holmbom, Willför, \& Murzin, 2011a; Pereira, Couto, \& Anna, 2008). Chemical or enzymatic processes can be converted into hydroxymethylfurfural (HMF) which is an important intermediate platform for the production of dimethylfuran (DMF) or furan-based polymers

(Pereira et al., 2008)• 


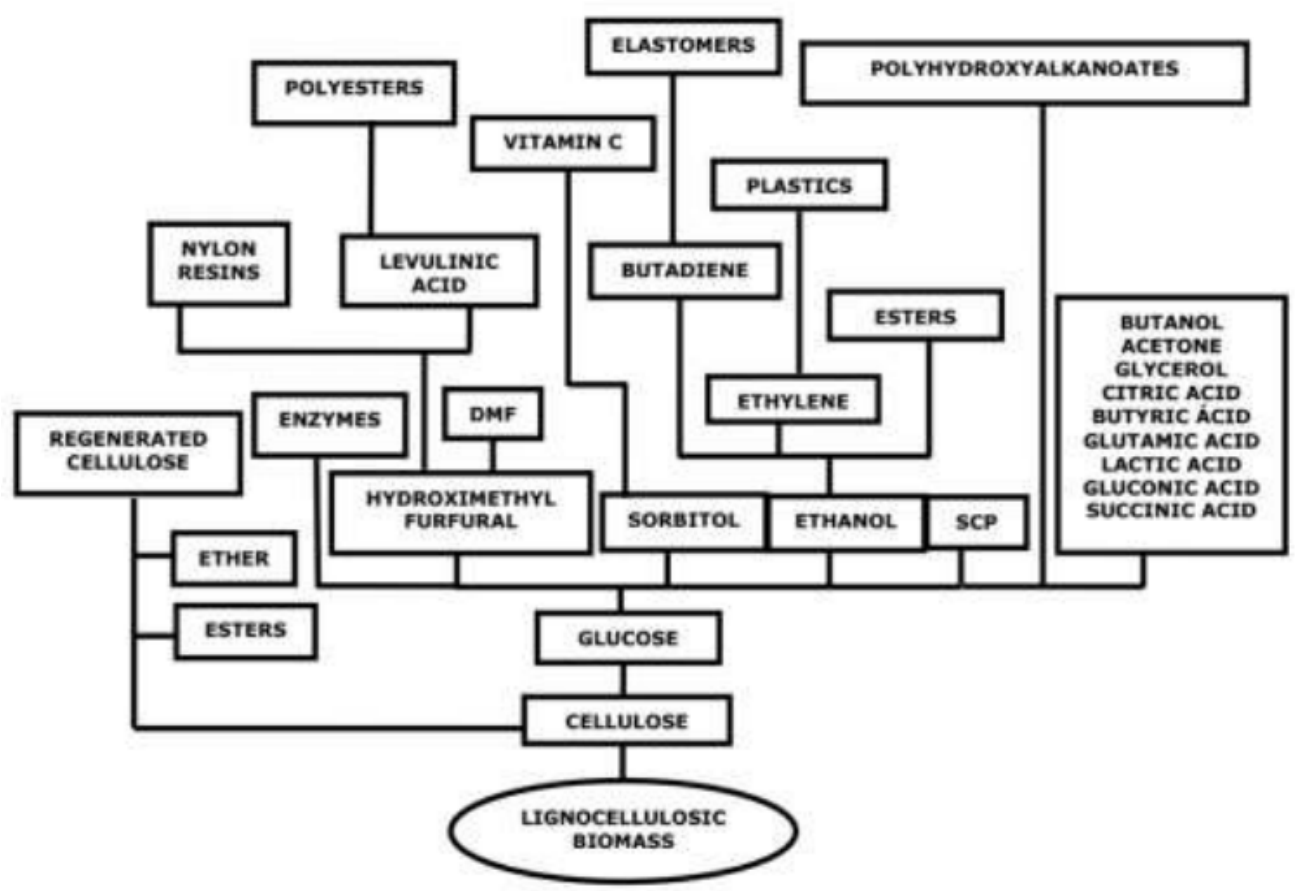

Figure 2 Schematic concepts of biorefinery from lignocellulosic biomass composition (cellulose products) (Pereira et al., 2008).

\subsection{Hemicellulose}

Hemicellulose $\left(\mathrm{C}_{5} \mathrm{H}_{8} \mathrm{O}_{4}\right)_{n}$ is a short, highly branched polymer of pentose sugars (D-xylose and L-arabinose) and hexose (D-glucose, D-mannose and D-galactose) (Kuhad, Gupta, Khasa, Singh, \& Zhang, 2011). Hemicelluloses are associated to cellulose as large source of carbon in plants and xyloglucans or xylans depending on the types of plants (Bioprocessing, Fuels, \& Energy, 1994). The presiding sources of hemicelluloses biomass are woody, softwoods, and hardwoods (Limayem \& Ricke, 2012). Hemicellulose is more readily hydrolyzed compared to cellulose because of its branched, amorphous nature.

Xylose can be hydrogenated to produce xylitol, which can be used as a non-carcinogenic sweetener, with the same sweetening power of sucrose and with metabolization in the humans independent of insulin. Xylose can be biologically converted to single cell proteins (SCP) and to a variety of fuels and solvents, such as bioethanol by yeasts with the ability to ferment pentose (Pichia stipitis, Candida sheratae) (Pereira et al., 2008). Xylitol, by microorganisms with exclusively nicotinamide adenine dinucleotide phosphate (NADPH) dependent reductase activities on xylose (Vásquez, De Souza, \& Pereira, 2006); biopolymers (polyhydroxyalkanoates, polylactate etc); a series of organic acids (succinic, propionic, acetic, lactic and butyric); solvents (butanol and acetone) and other fuels or fuel additives (DMF, butanol, 2,3 butanediol) (Clark \& Deswarte, 2015) (Fig. 3). 
Bioethanol Production Techniques from Lignocellulosic Biomass as Alternative Fuel: A Review

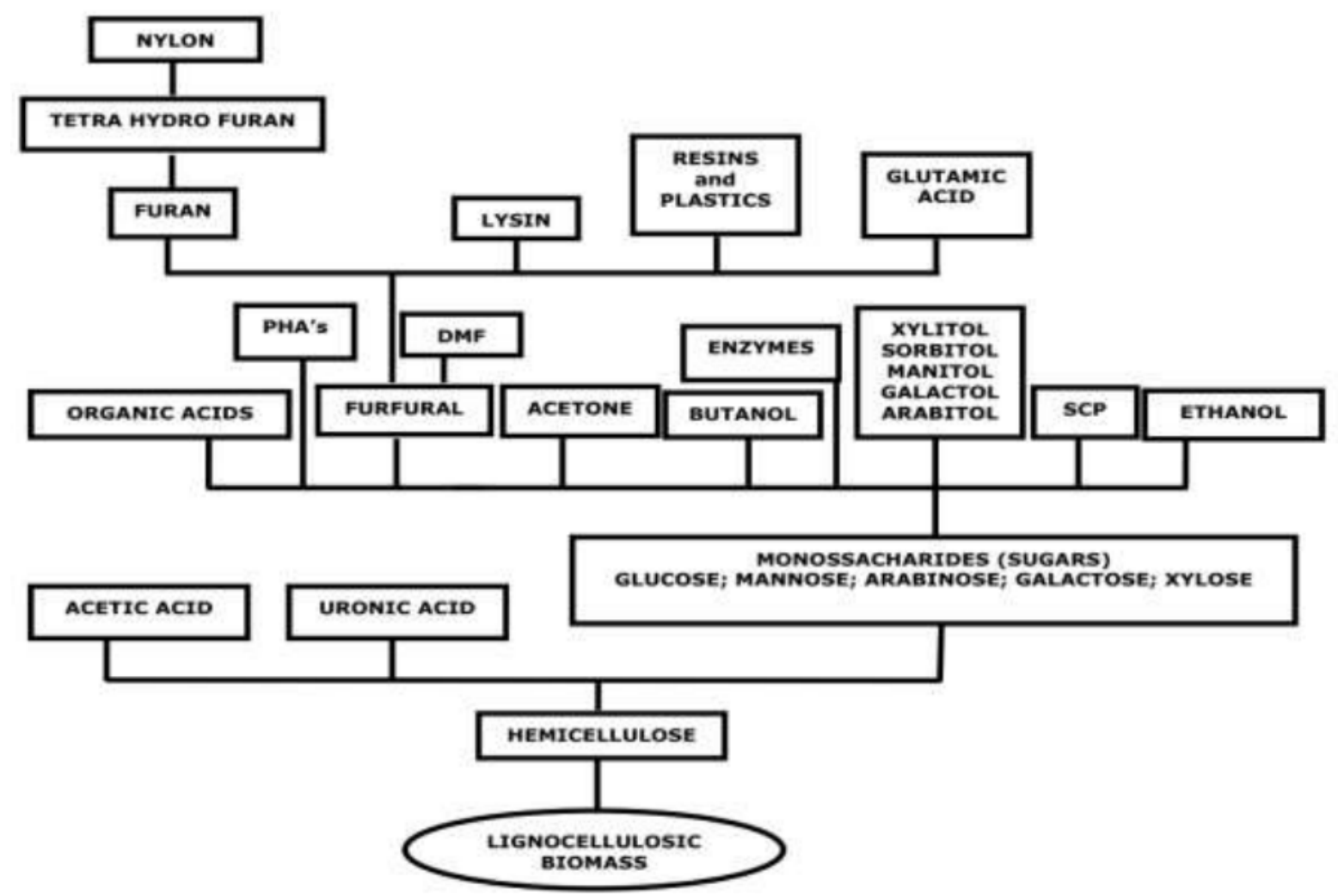

Figure 3 Schematic concepts of biorefinery from lignocellulosic biomass composition (hemicellulose products) (Pereira et al., 2008).

\subsection{Lignin}

Lignin $\left[\mathrm{C}_{9} \mathrm{H}_{10} \mathrm{O}_{3}\left(\mathrm{OCH}_{3}\right)_{0.9-1.7}\right]_{\mathrm{n}}$ is an organic compound from three different monomers (coniferyl, synapyl alcohols, and p-coumaryl) joined together by a set of linkages to create a matrix (Sánchez, 2009). This matrix consist of various functional groups, such as methoxyl, hydroxyl, and carbonyl, which shows a high polarity to the lignin macromolecule (Feldman, Banu, Natansohn, \& Wang, 1991). Lignin is among the obstacles to fermentation of LCB, which makes it unaffected by chemical and biological degradation, but affects the quality of bioethanol production (Taherzadeh \& Karimi, 2008).

Lignin offers useful opportunities to obtain high-value products, such as carbon fibers, emulsifiers, dispersants, sequestrants, surfactants, binders and aromatics (Rosas, Berenguer, Valero-Romero, RodrÃguez-Mirasol, \& Cordero, 2014). The application of lignin is in the pulp and paper industry, which serve as a biofuel to replace fossil fuels for transportation, and the lignin-depleted black liquor can be reused in the cooking operation (Pereira et al., 2008) (Fig. 4). 


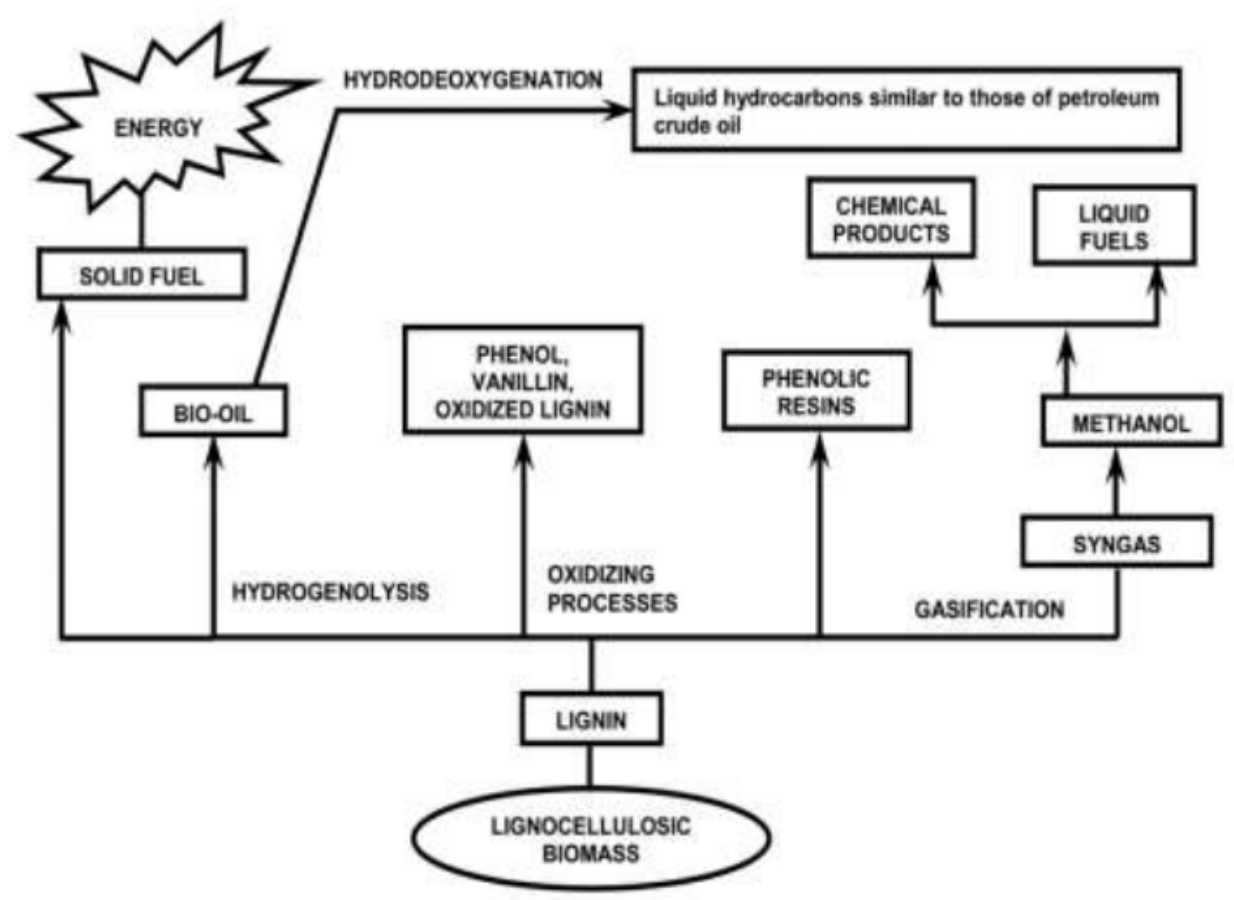

Figure 4 Schematic concepts of biorefinery from lignocellulosic biomass composition (lignin products) (Pereira et al., 2008).

\section{PROCESS OF CONVERTING LIGNOCELLULOSIC BIOMASS TO BIOETHANOL}

The conversion process of ethanol depends on the types of LCB used. Generally, bioethanol production from LCB comprises different stages: (1) pretreatment (2) hydrolysis of cellulose and hemicellulose (3) sugar fermentation and (4) distillation and purification of the ethanol to meet fuel specifications (Bon \& Ferrara, 2010; Demirbaş, 2005).

\subsection{Pretreatment technologies}

This process has an essential effect on the overall process of bioethanol from LCB, which makes the cellulose accessible to hydrolysis for conversion to ethanol fuels (Srichuwong et al., 2009). Various pretreatment techniques change the properties and structure of the LCB, and improve the rate hydrolysis (P. Kumar et al., 2009). Pretreatment technologies are divided into four categories: (1) physical (Keikhosro Karimi \& Taherzadeh, 2016) (2) physico-chemical (Bonner et al., 2016) (3) chemical (Williams, Crowe, Ong, \& Hodge, 2017) and (4) biological pretreatment (Amin et al., 2017). The advantages and disadvantages of the pretreatment processes for LCB materials are summarized in Table 1.

\subsubsection{Physical pretreatment}

Physical pretreatment is a process of reducing the particle size of the feedstock to increase the surface or volume ratio, which eases the subsequent processes in the production (Harmsen, Huijgen, López, \& Bakker, 2010). Saccharification produces fermentable sugars from cellulosic materials via enzymatic degradation, acidic, and ionic hydrolysis (C. Zhao et al., 2018). The types of physical pretreatment appear below.

\subsubsection{Mechanical}

Mechanical pretreatment of LCB is an important step for improving the bioconversion potential through particle densification and distribution, enzymatic accessibility, and the overall 
transformation of lignocellulosic material into biofuels without the generation of toxic side streams (Barakat et al., 2014). This process involves the breakdown of LCB through a combination of chipping, grinding, or milling which reduces cellulose crystallinity (Cheng \& Timilsina, 2011). It can be considered environmentally friendly because it does not require additional chemicals (Inoue, Yano, Endo, Sakaki, \& Sawayama, 2008), and thus inhibitors are not generated (Da Silva, Inoue, Endo, Yano, \& Bon, 2010). The pretreatment process generates new surface area, improves flow properties, and increases the bulk density and porosity (Amin et al., 2017). The size of the materials is usually $10 \mathrm{~mm}$ to $30 \mathrm{~mm}$ after chipping and $0.2 \mathrm{~mm}$ to $2 \mathrm{~mm}$ after milling or grinding (Sun \& Cheng, 2002). The energy requirements are dependent on the final particle size and reduction in crystallinity of the lignocellulosic material (Brodeur et al., 2011). Zheng et al. (2009) reported that mechanical processes such as attrition milling, ball milling, and compression milling treatment could be used to destruct lignin and give better access for enzymes to attack cellulose and hemicellulose in enzymatic hydrolysis.

\subsubsection{Physico-chemical pretreatment}

\subsubsection{Steam explosion (auto-hydrolysis)}

Steam explosion is the most commonly used method for the pretreatment of lignocellulosic materials (Balat, 2011). It is also considered the most cost-effective option for hardwood and agriculture residues (Prasad, Singh, \& Joshi, 2007) but is less effective for softwood (Saini, Saini, \& Tewari, 2015) because of the low content of acetyl groups in the hemicellulosic portion of softwoods (Sun \& Cheng, 2002). In this method, LCB is exposed to high-pressure saturated steam at a temperature of $160^{\circ} \mathrm{C}$ to $260{ }^{\circ} \mathrm{C}$ and a corresponding pressure of $5 \mathrm{~atm}$ to $50 \mathrm{~atm}$ for a few minutes (Heerah, Mudhoo, Mohee, \& Sharma, 2008). The gradual release of pressure, and the steam swell in a lignocellulosic matrix, causing individual fibers to separate and the cell wall structure to be disrupted (Agbor, Cicek, Sparling, Berlin, \& Levin, 2011). Acid can be added as a catalyst during steam explosion, but addition of acid is not mandatory. Steam pretreatment is termed auto-hydrolysis if no exogenous acid catalyst is added to the plant biomass (Amin et al., 2017). The increase in $\mathrm{SO}_{2}$ or sulfuric acid $\left(\mathrm{H}_{2} \mathrm{SO}_{4}\right)$ has been proposed as one of the most effective pretreatment methods for softwood material, but it has some disadvantages (Berlin et al., 2006; L. Kumar, Arantes, Chandra, \& Saddler, 2012).

\subsubsection{Ammonia fiber explosion (AFEX)}

This process utilizes ammonia to decrease crystallinity of cellulose in lignocellulosic biomass, as well as to disrupt carbohydrate lignin bonds (Maurya, Singla, \& Negi, 2015). In this process, liquid ammonia is added to the biomass under moderate pressure (100 psi to $400 \mathrm{psi}$ ) and temperature $\left(70{ }^{\circ} \mathrm{C}\right.$ to $\left.200{ }^{\circ} \mathrm{C}\right)$ before rapidly releasing the pressure. The main process parameters are the temperature of the reaction, residence time, ammonia loading, and water loading (Bals, Rogers, Jin, Balan, \& Dale, 2010). Ammonia fiber explosion pretreatment increases the lignocellulosic digestibility and enhances the yield from the enzymatic hydrolysis as the subsequent process (Taherzadeh \& Karimi, 2008). Research by (R. Kumar, Mago, Balan, \& Wyman, 2009) reported that the ammonia fiber explosion method shows no inhibition of the subsequent processes in the production line, and cell walls extractives, for instance lignin phenolic fragments, remain on the surface of cellulose. Alizadeh et al. (2005) pretreated switchgrass (Panicum virgatum) using ammonia fiber explosion at $100{ }^{\circ} \mathrm{C}$ with ammonia to biomass ratio of $1: 1$, yielding $0.2 \mathrm{~g}$ ethanol/g dry biomass. It was observed that enzyme formulation produced high sugar yields. With switch grass as the biomass, $520 \mathrm{~g}$ sugar $/ \mathrm{kg}$ biomass was released after enzymatic hydrolysis, while $410 \mathrm{~g}$ sugar $/ \mathrm{kg}$ biomass is normally released (Bals et al., 2010). 


\subsubsection{Chemical pretreatment}

\subsubsection{Acid pretreatment}

This process is used more often than biological or physical pretreatment methods because it is more effective and enhances the biodegradation of complex materials (Zhou, Zhang, \& Dong, 2012). In this method, dilute sulfuric acid $\left(\mathrm{H}_{2} \mathrm{SO}_{4}\right)$ is the most commonly used (Us \& Perendeci, 2012), because it has high efficiency in the separating process of cell wall components resulting in hemicellulose hydrolysate and cellulignin (Bardone et al., 2014; Harmsen et al., 2010; Pandey, Larroche, Ricke, Dussap, \& Gnansounou, 2011). However, other acidic substances such as hydrochloric acid $(\mathrm{HCl})$ (Pakarinen, Kaparaju, \& Rintala, 2011), oxalic acid $\left(\mathrm{C}_{2} \mathrm{H}_{2} \mathrm{O}_{4}\right)$ (Anuj K Chandel, Silva, Singh, Silvério, \& Singh, 2012), and acetic acid $\left(\mathrm{CH}_{3} \mathrm{COOH}\right)$ (Monlau, Latrille, Da Costa, Steyer, \& Carrère, 2013) have also shown promising results. The process can be performed at temperature ranges of between $120^{\circ} \mathrm{C}$ and $180{ }^{\circ} \mathrm{C}$ and residence times ranging between $15 \mathrm{~min}$ and $60 \mathrm{~min}$. The low temperature for this process makes it a low cost pretreatment, and it can at least loosen the cell wall matrix through hemicellulose degradation (Alvira, Tomás-Pejó, Ballesteros, \& Negro, 2010). The process does not affect lignin, but cellulose microfibrils are sufficient to produce a high yield of monomeric sugars for fermentation (Taherzadeh \& Karimi, 2008; Vohra, Manwar, Manmode, Padgilwar, \& Patil, 2014). In a similar study, Tang et al. (2013) employed acid pretreatment of Eulaliopsis binate using dilute sulfuric acid. It was found that $21.02 \%$ of total sugars were produced with low inhibitor levels after being pretreated by $0.5 \%$ dilute sulfuric acid at $160{ }^{\circ} \mathrm{C}$ for $30 \mathrm{~min}$ and at a solid-to-liquor ratio of 1:5.

Inhibitor formation and the hydrolysis of lignocellulose are a function of pretreatment severity, which is influenced by the acid concentration, reaction temperature, and retention time. Overend et al. (Overend, Chornet, \& Gascoigne, 1987) developed an equation that involves the reaction time and temperature, which indicates the severity of the pretreatment by combined severity factor (CSF). These relationships are indicated in equation (1).

$$
\mathrm{CSF}=t_{\exp }\left[\frac{\left(T-T_{r e f}\right)}{14.75}\right]
$$

Where $t$ is the residence time $(\mathrm{min}) ; T$ is the temperature $\left({ }^{\circ} \mathrm{C}\right)$, and $T_{\text {ref }}$ is the reference temperature, usually set to $100^{\circ} \mathrm{C}$.

\subsubsection{Alkali pretreatment}

This pretreatment process is applied in a simple operation and gives high conversion yields within only a short period (Harmsen et al., 2010). This process utilizes lower temperatures and pressures than other pretreatment technologies (Yi Zheng et al., 2009) and causes less sugar degradation, but the inhibitors are usually eliminated in order to optimize the pretreatment conditions (Canilha et al., 2012). Alkali reagents such as potassium hydroxide ( $\mathrm{KOH})$, sodium hydroxide $(\mathrm{NaOH})$, hydrazine $\left(\mathrm{N}_{2} \mathrm{H}_{2}\right)$, anhydrous ammonia $\left(\mathrm{NH}_{3}\right)$ and calcium hydroxide $\mathrm{Ca}(\mathrm{OH}) 2$ are typically featured in alkali pretreatment of biomass (Sebayang et al., 2016). The pretreatment process using sodium hydroxide $(\mathrm{NaOH})$ is one of the most effective chemical pretreatments for ethanol production (J. S. Kim, Lee, \& Kim, 2016) and can enhance the swelling characteristics, which is accompanied by a higher accessible area (Keikhosor Karimi, Shafiei, \& Kumar, 2013), as well as cause a decrease in crystallinity and polymerization degree (Mosier et al., 2005). In general, this pretreatment is more effective on the hardwood, herbaceous crops, and agricultural residues with low lignin content and high lignin content in softwood (Bjerre, Olesen, Fernqvist, Plöger, \& Schmidt, 1996). Playne (Playne, 1984) pretreated rice straw using alkali chemicals $(\mathrm{NaOH}, \mathrm{Ca}(\mathrm{OH}) 2$ and $\mathrm{KOH})$ in $24 \mathrm{~h}$ at $25^{\circ} \mathrm{C}$, and found that $\mathrm{NaOH}(6 \%$ chemical loading, $\mathrm{g} / \mathrm{g}$ dry rice straw) was the best alkali chemical to 
achieve $85 \%$ increase of glucose yield by enzymatic hydrolysis. Bali et al. (Bali, Meng, Deneff, Sun, \& Ragauskas, 2015) studied the effect of different pretreatment methods and found that the highest increase in cellulose accessibility was with dilute $\mathrm{NaOH}$ solution, followed by methods using $\mathrm{NH}_{4} \mathrm{OH}$ soaked in $\mathrm{Ca}(\mathrm{OH})_{2}$ solution.

\subsubsection{Ozonolysis pretreatment}

Ozone $\left(\mathrm{O}_{3}\right)$ is a powerful oxidant, soluble in water and is readily available. It is highly reactive toward compounds incorporating conjugated double bonds and functional groups with high electron densities. The most likely biomass constituent to be oxidized is lignin due to its high content of $\mathrm{C}=\mathrm{C}$ bonds (García-Cubero, González-Benito, Indacoechea, Coca, \& Bolado, 2009). Ozone is used to degrade the lignin and hemicellulose fractions from many lignocellulosic materials such as bagasse, wheat straw, pine, peanut, cotton straw, and poplar sawdust (P. Kumar et al., 2009). Ozonolysis cleaves carbon-carbon bonds which can occur at high temperatures or in catalytic beds; hence less pollution is ejected into the environment (P. Kumar et al., 2009). Gitifar et al. (2013) employed the ozonization of sugarcane bagasse previously treated with diluted sulfuric acid in an autoclave. The results showed that delignification and sugar production increased by applying the acid pretreatment; no data about degradation compounds was provided. Travaini et al. (Travaini, Otero, Coca, Da-Silva, \& Bolado, 2013) studied the effect of sugarcane bagasse in a fixed bed reactor. It was found that a $46 \%$ of glucose yield was obtained at $80 \%(\mathrm{w} / \mathrm{w})$ moisture content, six percentage points more than at $40 \%(\mathrm{w} / \mathrm{w})$ moisture content, and concluded that low water content favored inhibitory compound formation. Karunanithy et al. (2014) reported that sequential extrusion-ozone pretreatment improved sugar recoveries. When compared with control samples, glucose, xylose, and total sugar recovery rates attained increases of 3.42, 5.01, and 3.42 times for switchgrass and of 4.5, 2.7, and 3.9 times for big bluestem.

\subsubsection{Ionic Liquids (ILs)}

Ionic liquids (ILs) are organic salts composed of organic cations and either organic or inorganic anions. Four groups of cations are mainly used for categorizing ionic liquids: quaternary ammonium, N-alkylpyridinium, N-alkyl-isoquinolinium, and 1-alkyl-3-methylimidazolium (C. Z. Liu, Wang, Stiles, \& Guo, 2012). Besides being a powerful solvent for cellulose, ILs have unique properties such as low vapor pressure and high thermal and chemical stability. The desired property is adjustable by the selection of appropriate cations and anions (Keikhosor Karimi et al., 2013). Other factors to be considered when choosing an IL for pretreatment are the price, physical properties, availability, toxicity, corrosivity, biodegradability, and water tolerance (P. Mäki-Arvela, Anugwom, Virtanen, Sjöholm, \& Mikkola, 2010). Among the ILs, $[\mathrm{EMIM}][\mathrm{Ac}]$ and $[\mathrm{BMIM}][\mathrm{Cl}]$ are mostly used for pretreatment of lignocellulosic materials, and efficient solvents for lignocelluloses (P. Mäki-Arvela et al., 2010). Certain ILs can cause cellulose dissolution, structural modification, and even its direct hydrolysis (C. Z. Liu et al., 2012). Residual ILs remaining in the biomass could interfere with hydrolytic enzyme activities and downstream fermentation steps (Sathitsuksanoh, Zhu, \& Zhang, 2012; Shi et al., 2013). It may affect the final sugar and biofuel yields. After regeneration, ILs can be recovered from anti-solvents by flash distillation and be reused (Joglekar, Rahman, \& Kulkarni, 2007).

\subsubsection{Biological pretreatments}

Biological pretreatment of LCB is considered an efficient, eco-friendly and cheap alternative (Wan \& Li, 2012). There are several microorganisms which can naturally assimilate inhibitory compounds, including yeasts (Saccharomyces cerevisiae), fungi, and bacteria (Parawira \& Tekere, 2011). Some microorganisms during incubation are able to release cellulase and 
hemicellulase and degrade only lignin, resulting in a lignocellulosic substrate which can be easily hydrolyzed into fermentable sugars with mild conditions and in a short time (A K Chandel, Chandrasekhar, Radhika, \& Ravinder, 2011). The commonly used microorganisms are filamentous fungi which are ubiquitous and can be isolated from the soil, living plants or lignocellulosic waste material (Vats, Maurya, Shaimoon, Agarwal, \& Negi, 2013). Generally, wood degrading microorganisms like bacteria and brown rot, white rot, and soft rot fungi are employed in biological pretreatment (Hage et al., 2009). Fungi have distinct degradation characteristics on LCB. Brown rot fungi mainly attack cellulose, while white and soft rot fungi attack both cellulose and lignin (Sun \& Cheng, 2002). The advantages and disadvantages of different pretreatment processes for LCB materials are summarized in Table 1.

Table 1 Advantages and disadvantages of different pretreatment processes for lignocellulosic biomass materials.

\begin{tabular}{|c|c|c|c|c|}
\hline \begin{tabular}{|c} 
PRETREATMENT \\
METHOD \\
\end{tabular} & PROCESS & ADVANTAGES & DISADVANTAGES & REFERENCE \\
\hline Physical & $\begin{array}{l}\text { Mechanical: } \\
\text { Physical reduction } \\
\text { in substrate particle } \\
\text { size by grinding, } \\
\text { milling, etc. }\end{array}$ & $\begin{array}{l}\text { Reduces } \\
\text { cellulose } \\
\text { crystallinity and } \\
\text { degree of } \\
\text { polymerization } \\
\text { Reduced the } \\
\text { particle size to } \\
\text { increase a } \\
\text { specific surface } \\
\text { area }\end{array}$ & $\begin{array}{l}\text { Power consumption } \\
\text { usually higher than } \\
\text { inherent biomass } \\
\text { energy }\end{array}$ & (Balat, 2011) \\
\hline \multirow{3}{*}{ Physico-chemical } & $\begin{array}{l}\text { Steam explosion: } \\
\text { Substrate particles } \\
\text { rapidly heated by } \\
\text { high-pressure } \\
\text { saturated steam. } \\
\text { Explosive } \\
\text { decompression } \\
\text { caused by quick } \\
\text { release of pressure } \\
\text { acids released to aid } \\
\text { in hemicellulose } \\
\text { hydrolysis. }\end{array}$ & $\begin{array}{l}\text { Cost-effective } \\
\text { Causes lignin } \\
\text { transformation } \\
\text { and } \\
\text { hemicellulose } \\
\text { solubilization } \\
\text { High yield of } \\
\text { glucose and } \\
\text { hemicellulose in } \\
\text { the two-step } \\
\text { process }\end{array}$ & $\begin{array}{l}\text { Partial hemicellulose } \\
\text { degradation } \\
\text { Toxic compounds } \\
\text { generation } \\
\text { Acidic catalyst } \\
\text { needed to make the } \\
\text { process efficient } \\
\text { with high lignin } \\
\text { content material }\end{array}$ & $\begin{array}{l}\text { (Brodeur et al., } \\
\text { 2011) }\end{array}$ \\
\hline & $\begin{array}{l}\text { Ammonia fiber } \\
\text { explosion (AFEX): } \\
\text { Substrate is exposed } \\
\text { to hot liquid } \\
\text { ammonia under high } \\
\text { pressure. Pressure is } \\
\text { released suddenly } \\
\text { breaking open } \\
\text { biomass structure. }\end{array}$ & $\begin{array}{l}\text { Increases } \\
\text { accessible } \\
\text { surface area } \\
\text { Fewer inhibitors } \\
\text { formation } \\
\text { Does not require } \\
\text { a small particle } \\
\text { size of biomass }\end{array}$ & $\begin{array}{l}\text { Very high pressure } \\
\text { requirements } \\
\text { Expensive } \\
\text { Not very effective } \\
\text { for the biomass with } \\
\text { high lignin content }\end{array}$ & $\begin{array}{l}\text { (Gumisiriza, } \\
\text { Hawumba, } \\
\text { Okure, \& Hensel, } \\
\text { 2017) }\end{array}$ \\
\hline & $\begin{array}{l}\mathrm{CO} 2 \text { explosion: } \\
\text { Injected to the } \\
\text { biomass reactor in }\end{array}$ & $\begin{array}{l}\text { Increases } \\
\text { accessible } \\
\text { surface area }\end{array}$ & $\begin{array}{l}\text { Very high pressure } \\
\text { requirements }\end{array}$ & $\begin{array}{l}\text { (Maurya et al., } \\
\text { 2015; Sebayang } \\
\text { et al., 2016) }\end{array}$ \\
\hline
\end{tabular}


Bioethanol Production Techniques from Lignocellulosic Biomass as Alternative Fuel: A Review

\begin{tabular}{|c|c|c|c|c|}
\hline $\begin{array}{l}\text { PRETREATMENT } \\
\text { METHOD }\end{array}$ & PROCESS & ADVANTAGES & DISADVANTAGES & REFERENCE \\
\hline & $\begin{array}{l}\text { very high pressure } \\
\text { and heated at high } \\
\text { temperature. }\end{array}$ & $\begin{array}{l}\text { Non- } \\
\text { flammability } \\
\text { Do not form } \\
\text { inhibitory } \\
\text { compounds } \\
\text { Availability at } \\
\text { relatively low } \\
\text { cost } \\
\text { Easy recovery } \\
\text { after extraction } \\
\text { and } \\
\text { environmental } \\
\text { acceptance }\end{array}$ & $\begin{array}{l}\text { A portion of xylan } \\
\text { fraction lost } \\
\text { It can emit the } \mathrm{CO} 2 \\
\text { emission to the } \\
\text { atmosphere }\end{array}$ & \\
\hline \multirow{3}{*}{ Chemical } & $\begin{array}{l}\text { Acid: Addition of } \\
\text { dilute or } \\
\text { concentrated acid } \\
\text { solutions result in } \\
\text { hemicellulose } \\
\text { hydrolysis (H2SO4, } \\
\text { HCl, HNO3, } \\
\text { H3PO4). }\end{array}$ & $\begin{array}{l}\text { High glucose } \\
\text { yield } \\
\text { High } \\
\text { concentration } \\
\text { can be done at } \\
\text { room } \\
\text { temperature } \\
\text { Solubilizes } \\
\text { hemicellulose }\end{array}$ & $\begin{array}{l}\text { High operational and } \\
\text { maintenance costs } \\
\text { Corrosive } \\
\text { Formation of } \\
\text { inhibitors } \\
\text { Concentrated acids } \\
\text { are toxic and } \\
\text { hazardous }\end{array}$ & $\begin{array}{l}\text { (A. K. Kumar \& } \\
\text { Sharma, 2017) }\end{array}$ \\
\hline & $\begin{array}{l}\text { Alkali: Addition of } \\
\text { base causes } \\
\text { swelling, increasing } \\
\text { the internal surface } \\
\text { of cellulose which } \\
\text { provokes lignin } \\
\text { structure disruption } \\
(\mathrm{NaOH}, \mathrm{KOH}, \\
\mathrm{Lime}, \mathrm{Mg}(\mathrm{OH}) 2, \\
\mathrm{NH} 4 \mathrm{OH}) .\end{array}$ & $\begin{array}{l}\text { Decreased } \\
\text { cellulose } \\
\text { crystallinity and } \\
\text { degree of } \\
\text { polymerization } \\
\text { Can be done at } \\
\text { room } \\
\text { temperature } \\
\text { Efficient } \\
\text { removal of lignin }\end{array}$ & $\begin{array}{l}\text { Relatively expensive } \\
\text { Not used for large } \\
\text { scale plant } \\
\text { Irrecoverable salts } \\
\text { formed and } \\
\text { incorporated into } \\
\text { biomass }\end{array}$ & $\begin{array}{l}\text { (Bali et al., 2015; } \\
\text { Rabemanolontsoa } \\
\& \text { Saka, 2016) }\end{array}$ \\
\hline & $\begin{array}{l}\text { Ozonolysis: } \\
\text { Powerful oxidant, } \\
\text { soluble in water and } \\
\text { is readily available. }\end{array}$ & $\begin{array}{l}\text { Reduces lignin } \\
\text { content } \\
\text { Does not } \\
\text { produce toxic } \\
\text { residues } \\
\text { No requirement } \\
\text { of chemical } \\
\text { additives } \\
\text { Operation at } \\
\text { ambient } \\
\text { temperature and } \\
\text { pressure }\end{array}$ & $\begin{array}{l}\text { Relatively expensive } \\
\text { due to a large } \\
\text { amount of ozone } \\
\text { generated } \\
\text { Highly reactive, } \\
\text { flammable, } \\
\text { corrosive and toxic } \\
\text { characteristics of } \\
\text { ozone }\end{array}$ & $\begin{array}{l}\text { (Travaini, } \\
\text { Martín-juárez, } \\
\text { Lorenzo- } \\
\text { hernando, \& } \\
\text { Bolado- } \\
\text { rodríguez, 2016) }\end{array}$ \\
\hline
\end{tabular}


Abdulfatah Abdu Yusuf and Freddie L. Inambao

\begin{tabular}{|c|c|c|c|c|}
\hline $\begin{array}{l}\text { PRETREATMENT } \\
\text { METHOD }\end{array}$ & PROCESS & ADVANTAGES & DISADVANTAGES & REFERENCE \\
\hline & $\begin{array}{l}\text { Ionic Liquids (ILs): } \\
\text { Organic salts } \\
\text { composed of } \\
\text { organic cations and } \\
\text { either organic or } \\
\text { inorganic anions } \\
([\text { EMIM][Ac], } \\
{[\text { BMIM][Cl]). }}\end{array}$ & $\begin{array}{l}\text { Highly efficient } \\
\text { (over } 80 \% \\
\text { saccharification } \\
\text { yield) } \\
\text { Environmental } \\
\text { friendly } \\
\text { chemicals } \\
\text { Minor } \\
\text { degradation of } \\
\text { raw materials } \\
\text { Negligible } \\
\text { production of } \\
\text { inhibitory } \\
\text { compounds }\end{array}$ & $\begin{array}{l}\text { Very expensive } \\
\text { Has negative effects } \\
\text { on cellulose activity } \\
\text { and affect the final } \\
\text { yield of cellulose } \\
\text { hydrolysis } \\
\text { Consume much } \\
\text { water }\end{array}$ & $\begin{array}{l}\text { (Keikhosor } \\
\text { Karimi et al., } \\
\text { 2013) }\end{array}$ \\
\hline Biological & $\begin{array}{l}\text { Fungi and } \\
\text { actinomycetes: } \\
\text { Microorganisms } \\
\text { degrade and alter } \\
\text { biomass structure } \\
\text { (white-, brown-, } \\
\text { soft-rot fungi). }\end{array}$ & $\begin{array}{l}\text { Low energy } \\
\text { consumption } \\
\text { Simple } \\
\text { equipment } \\
\text { degrades lignin } \\
\text { and } \\
\text { hemicelluloses } \\
\text { Relatively } \\
\text { inexpensive } \\
\text { Does not cause } \\
\text { corrosion to the } \\
\text { equipment } \\
\text { Low production } \\
\text { of inhibitors }\end{array}$ & $\begin{array}{l}\text { A rate of hydrolysis } \\
\text { is very low } \\
\text { Low degradation } \\
\text { rate to attain a high } \\
\text { degree of lignin } \\
\text { degradation }\end{array}$ & $\begin{array}{l}\text { (P. Kumar et al., } \\
2009)\end{array}$ \\
\hline
\end{tabular}

\subsection{Hydrolysis}

Pretreatment is a crucial step for any lignocelluloses before hydrolysis (saccharification). Different pretreatments have been reported in the literature which makes substrates more conducive for hydrolysis. Researchers have recently reported many different methods for the hydrolysis of LCB materials. The most commonly applied methods are classified into two groups: enzymatic hydrolysis and acid hydrolysis (dilute and concentrated).

\subsubsection{Enzymatic hydrolysis}

Enzymatic hydrolysis uses enzymes (cellulases and xylanases) to hydrolyze cellulose and hemicellulose to fermentable sugars (Jain, Dey, Kumar, \& Kuhad, 2015). The major challenge for ethanol production is the cost of producing the enzyme complexes (Laisa dos Reis et al., 2013; Laísa dos Reis, Schneider, Fontana, Camassola, \& Dillon, 2014; G. Liu, Zhang, \& Bao, 2016). However, the advancement of technologies in enzyme manufacturing is likely to bring about a reduction in enzyme price. There are many reports of the commercial applications of lignocellulolytic enzymes, especially cellulase. The production of enzymes, for instance, cellulase, can be extracted from fungi and bacteria. The main fungi involved include: Trichoderma reesei (Brethauer \& Studer, 2014; Martins, Kolling, Camassola, Dillon, \& Ramos, 
2008; Wu et al., 2016), Penicillium echinulatum (Camassola \& Dillon, 2014; Scholl et al., 2015), Thermoascus aurantiacus (Jain et al., 2015), Trichoderma longibrachiatum (Shaibani, Yaghmaei, Andalibi, \& Ghazvini, 2012), and Trichoderma viride (Nathan, Rani, Rathinasamy, Dhiraviam, \& Jayavel, 2014). Meanwhile, the typical cellulase-producing bacteria include Acetivibrio (Du et al., 2015), Bacteriodes (Elshaghabee et al., 2016), Bacillus (Romero, Merino, Bolívar, Gosset, \& Martinez, 2007), Cellulomonas (Kojima, Okamoto, \& Yanase, 2013), Clostridium (Patankar, Dudhane, Paradh, \& Patil, 2018), Erwini (Tolan \& Finn, 1987), Ruminococcus (Yanning Zheng, Kahnt, Kwon, Mackie, \& Thauer, 2014), Streptomyces and Thermomonospora (Ventorino et al., 2016).

Various factors affect enzymatic hydrolysis, namely: substrates, cellulase activity, reaction conditions (temperature, $\mathrm{pH}$ as well as other parameters), and a strong product inhibition (Balat, 2011). To improve the yield and rate of enzymatic hydrolysis, research has been focused on optimizing the hydrolysis process and enhancing cellulase activity (Sun \& Cheng, 2002). The rate of enzymatic hydrolysis is dependent upon several structural parameters of the substrate (Pan, Gilkes, \& Saddler, 2006). The parameters known to affect the rate of hydrolysis include: (1) molecular structure, (2) crystallinity, (3) surface area of the fiber, (4) degree of swelling of the fiber, (5) degree of polymerization, and (6) associated lignin or other materials (Detroy \& St Julian, 1982).

Selig et al. (Selig et al., 2012) reported that commercial enzymatic cocktails often come with relatively high amounts of preservatives such as glycerol and sorbitol which have a negative effect on enzymatic hydrolysis. Arumugam and Manikandan (Arumugam \& Manikandan, 2011) studied the potential application of pulp and banana peel wastes in bioethanol production using dilute acid pretreatment followed by enzymatic hydrolysis. Cha et al. (Cha et al., 2014) pretreated Miscanthus sinensis grass using enzymatic hydrolysis with 20 FPU/g cellulose at $50{ }^{\circ} \mathrm{C}$ for $72 \mathrm{~h}$ and obtained $93.6 \%$ with $31.2 \mathrm{~g} / \mathrm{L}$ glucose by combined pretreatment of ammonia and $\mathrm{CO}_{2}$. Agudelo et al. (Agudelo, García-Aparicio, \& Görgens, 2016) found that the highest cellulose saccharification (92\%) of triticale straw was as a result of steam explosion pretreatment at $200{ }^{\circ} \mathrm{C}$ for $10 \mathrm{~min}$. Recent research by Patankar et al. (Patankar et al., 2018) obtained the maximum reducing sugars of $205 \mathrm{mg} / \mathrm{g}$ from corncobs and $100 \mathrm{mg} / \mathrm{g}$ from soybean cake as a result of treatment with $100 \mathrm{IU}$ cellulase for $48 \mathrm{~h}$ with $28 \%$ saccharification efficiency. The most recent comparative results of enzyme hydrolysis with individual sugars and total reducing sugars are shown in Table 2. The hydrolysis yield (\%) can be calculated using Equation 2 (Salehian \& Karimi, 2013).

$$
\text { Hydrolysis yield }(\%)=\frac{\text { Produced glucose }(g / L)}{1.111 \times \text { glucan in sample }(g / L)} \times 100
$$

Where the conversion factor of 1.111 was applied for hydration of glucan to glucose.

\subsubsection{Acidic hydrolysis}

Acidic hydrolysis can be divided into two types namely dilute and concentrated. Dilute acid hydrolysis is performed at a higher temperature using a low acid concentration while concentrated acid hydrolysis is carried out at a lower temperature using a high acid concentration. Dilute acid hydrolysis is the most commonly used process (Mohd Azhar et al., 2017) because it generates a large number of inhibitors compared to concentrated acid hydrolysis (Mohd Azhar et al., 2017). The goal of dilute acid hydrolysis is to remove hemicellulose selectively. The hydrolysis products may contain large oligomers. In this process, biomass can be hydrolyzed in a temperature range of $120^{\circ} \mathrm{C}$ to $220^{\circ} \mathrm{C}$ using dilute sulfuric acid $\left(\mathrm{H}_{2} \mathrm{SO}_{4}\right)$ as a catalyst. Under these conditions, nearly selective hydrolysis of hemicelluloses can be achieved, since it forms less glucose (Marzialetti et al., 2008). However, the optimum 
reaction conditions are selected from several interrelated parameters such as time, acid concentration, type of biomass and its concentration, making the comparison of different parameters difficult (Päivi Mäki-Arvela, Salmi, Holmbom, Willför, \& Murzin, 2011b).

Many studies have been carried out to investigate the effect of dilute as well as concentrated acid and enzymatic hydrolysis from different biomass sources (as reported in Table 3). Velásquez-Arredondo et al. (2010) investigated the acid hydrolysis of banana pulp and fruit and the enzymatic hydrolysis of flower stalk and banana skin, and the results obtained demonstrated a positive energy balance for the four production routes evaluated. Karimi et al. (2006) employed high pressure two-stage dilute acid hydrolysis $\left(1.0 \% \mathrm{H}_{2} \mathrm{SO}_{4}\right.$ in the first stage and 0.5 $\% \mathrm{H}_{2} \mathrm{SO}_{4}$ in the second) to obtain high conversion of $189 \mathrm{~g}$ xylose per $\mathrm{kg}$ and $29 \mathrm{~g}$ glucose per $\mathrm{kg}$ and considerable amounts of furfural and HMF of the rice straw used. Chamy et al. (1994) identified the best conditions for sugar beet pulp hydrolysis to be $1.1 \mathrm{~g} \mathrm{H}_{2} \mathrm{SO}_{4} / \mathrm{g}$ sugar beet pulp at $80{ }^{\circ} \mathrm{C}$ for $90 \mathrm{~min}$. Under such conditions, $86.3 \%$ and $7.8 \%$ of cellulose and hemicellulose hydrolysis, respectively, were obtained. In addition, untreated elephant grass is similar in cellulose composition to sugarcane bagasse, at around $36 \%$ cellulose (Menegol, Scholl, Fontana, Dillon, \& Camassola, 2014), while sugarcane bagasse contains $34 \%$ to $45 \%$ cellulose (Szczerbowski, Pitarelo, Zandoná Filho, \& Ramos, 2014).

\subsection{Fermentation}

This is a process of converting biomass into bioethanol by microorganisms such as yeast, fungi, and bacteria, which digest fermentable sugars and produce ethyl alcohol and other byproducts (Vohra et al., 2014). After pretreatment, the next steps are hydrolysis and fermentation, which can be carried out separately or simultaneously. The following processes are commonly used in the production of bioethanol: separate hydrolysis and fermentation (SHF), simultaneous saccharification and fermentation (SSF), and simultaneous saccharification and cofermentation (SSCF) (Mohd Azhar et al., 2017). Saccharomyces and Pichia are the most common hexose and pentose-fermenting yeasts used in bioethanol production under different conditions of fermentation (Tesfaw \& Assefa, 2014), as well as the bacteria Zymomonas and Escherichia and Aspergillus (Skotnicki, Warr, Goodman, Lee, \& Rogers, 1983). Most studies have employed S. cerevisiae as their microorganism. Yu and Zhang (2003) compared the ethanol yield by S. cerevisiae, Pichia sp. YZ-1 and Z. mobilis and obtained a maximal ethanol yield of $0.45 \mathrm{~g} / \mathrm{g}$ glucose by $S$. cerevisiae. Khawla et al. (2014) produced bioethanol from potato peel using both acid and enzyme hydrolysis. It was concluded that potato peel hydrolysate obtained from enzyme hydrolysis produced a higher ethanol yield compared to acid hydrolysate fermented by $S$. cerevisiae. This shows that the construction of engineered $S$. cerevisiae expressing cellulose is an important approach to degrading LCB materials (Kroukamp, den Haan, van Zyl, \& van Zyl, 2018).

The most recent studies on ethanol production from different LCB materials using enzymatic hydrolysis and fermentation by $S$. cerevisiae are reported in Table 3 . Ethanol yield can be calculated as a percentage of theoretical yield using Equation 3 (Bahmani, Shafiei, \& Karimi, 2016).

$$
\begin{array}{rr}
\text { Ethanol produced }(\mathrm{g} / \mathrm{L}) & \text { Ethanol yield }(\%)= \\
\hline 1.111 \times \text { initial weight of biomass in the fermentation medium }(\mathrm{g} / \mathrm{L}) \times 0.51 \times \text { glucan in sample }(\mathrm{g} / \mathrm{L}) & 100
\end{array}
$$

This review paper compares the types of fermentation processes, and each of the processes is discussed below.

\subsubsection{Simultaneous saccharification and fermentation (SSF)}


The process in which the cellulose is broken down and fermented at the same time in the presence of the microorganism is called simultaneous saccharification and fermentation (SSF) (South, Hogsett, \& Lynd, 1993; Sun \& Cheng, 2002). In SSF, the fungal cellulases are most active at $50{ }^{\circ} \mathrm{C}$ to $55{ }^{\circ} \mathrm{C}$, while the microbes ferment effectively at temperatures below $35{ }^{\circ} \mathrm{C}$ (Brodeur et al., 2011). This fermentation process has been the preferred step for the production of biofuels and chemicals because the operations of both hydrolysis and fermentation are conducted in the same reactor vessel thus reducing costs (Brodeur et al., 2011). This utilizes the sugars by fermenting organisms that could reduce the extent of feedback inhibition of enzymes and chances of contamination are also minimal due to the presence of ethanol in SSF (Stenberg, Bollók, Réczey, Galbe, \& Zacchi, 2000). However, the major disadvantage is that both saccharification and fermentation are carried out under suboptimal conditions (Galbe \& Zacchi, 2002). Fig. 5 describes the process of SSF.

Park et al. (2010) produced an ethanol yield of $74 \%$ of the theoretical value using a mixture of $S$. cerevisae and Pichiastipitis after $79 \mathrm{~h}$ of fermentation at $30{ }^{\circ} \mathrm{C}$ using the SSF process. Oberoi et al. (2011) optimized the bioethanol production from banana peels using enzyme hydrolysis and SSF by S. cerevisiae. Boluda-Aguilar et al. (2010) produced bioethanol from mandarin peel waste and obtained $6.8 \mathrm{~g}$ ethanol per $100 \mathrm{~g}$ biomass using SSF and the $S$. cerevisiae CECT1329 strain. The advantages and disadvantages of the SSF process as found by researchers are reported in Table 2 .

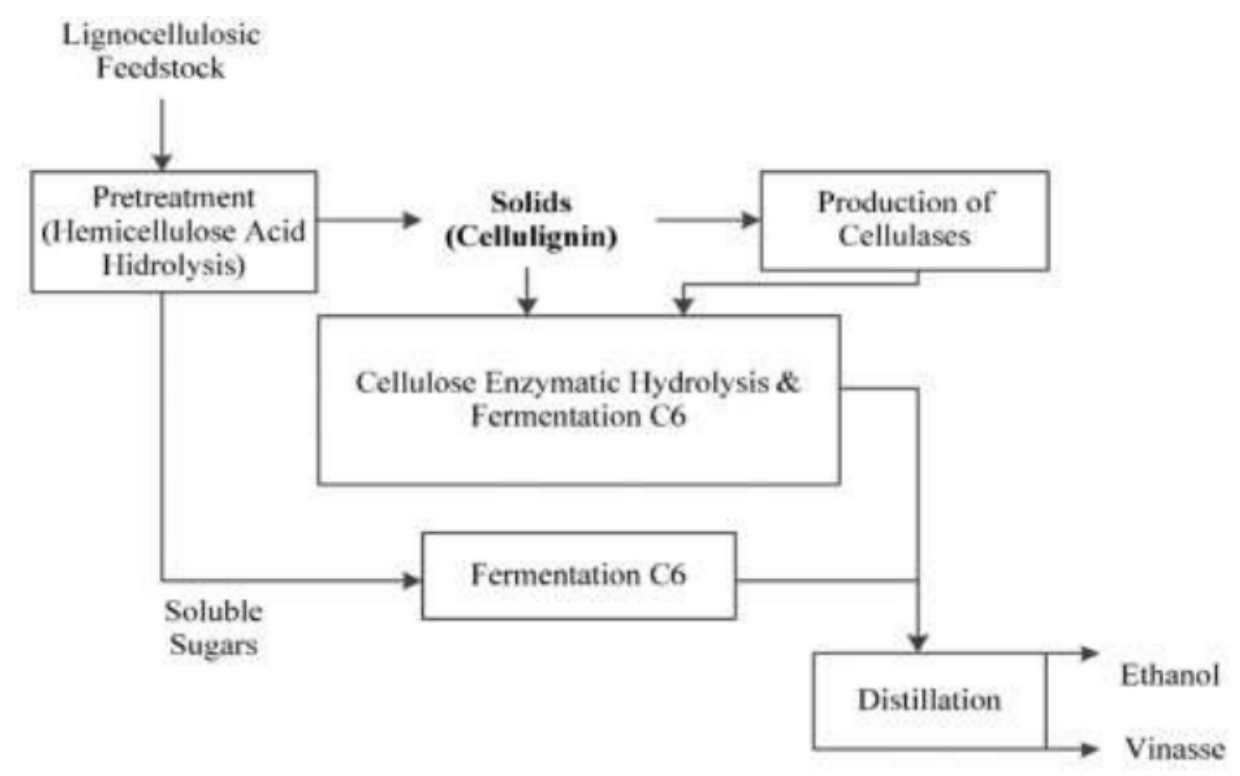

Figure 5 The schematic process of the simultaneous saccharification and fermentation (SSF) (Sebayang et al., 2016).

\subsubsection{Simultaneous saccharification and co-fermentation (SSCF)}

The SSCF fermentation technique utilizes the integration principle in employing mixed microbes to ferment more than one sugar type such as pentoses and hexoses (Buruiana, Garrote, \& Vizireanu, 2013; Sarkar et al., 2012). For the conversion of both pentoses and hexoses to ethanol, separate hydrolysis and co-fermentation (SHCF) or simultaneous saccharification and co-fermentation (SSCF) has been suggested (Dien, Cotta, \& Jeffries, 2003). The use of mixed microbes is limited by the respective ability of the microbes hexose-fermenting microbes usually grow faster than pentose-fermenting microbes, and this leads to a higher rate of ethanol conversion from hexose (Sebayang et al., 2016). 
Xylose assimilation in the former process suffers from glucose and ethanol inhibition (Jin, Gunawan, Balan, Lau, \& Dale, 2012). SSCF can be performed by two different or one recombinant microorganism (R. Kumar, Tabatabaei, Karimi, \& Sárvári Horváth, 2016). In SSCF, glucose inhibition is reduced; however, ethanol yield in SSCF from both glucose and xylose is considerably lower than that formed from glucose by ordinary yeasts (e.g., $S$ cerevisiae) (Koppram et al., 2013). This fermentation technique holds several beneficial characteristics (as reported in Table 2). According to the reviewed literature, cellulose hydrolysis can also coincide with fermentation in the presence (SScF) or absence (SSF) of hemicellulose. Fig. 6 shows the schematic process of simultaneous saccharification and cofermentation (SSCF).

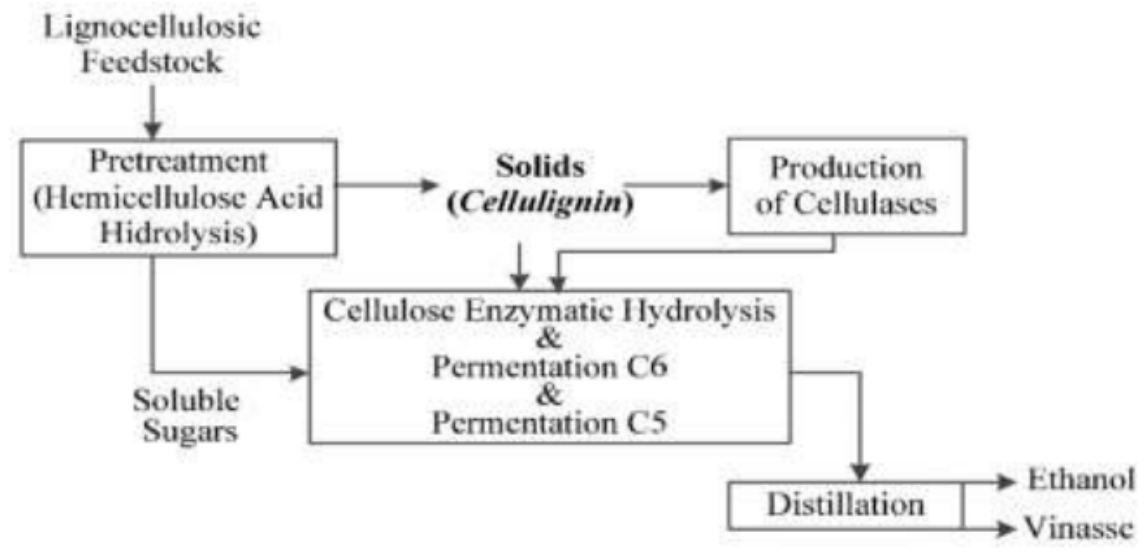

Figure 6 The schematic process of the simultaneous saccharification and co-fermentation (SSCF) (Sebayang et al., 2016).

\subsubsection{Separate hydrolysis and fermentation (SHF)}

In SHF, hydrolysis of LCB is performed separately from the fermentation step. In this process, each step can be conducted at optimal conditions of $\mathrm{pH}$ and temperature. However, glucose and cellobiose accumulation in the hydrolysis step inhibits the activity of the cellulases (Stenberg et al., 2000; Xiao, Zhang, Gregg, \& Saddler, 2004). SHF and SSF are complementary to one another in Table 2. This combination can be used for economic assessment and process optimization of the production process of ethanol from lignocellulosic materials. Fig. 7 presents a model which illustrates the process of separate hydrolysis and fermentation.

Choi et al. (2013) used the SHF process and obtained a maximum of $29.4 \mathrm{~g}$ ethanol from $100 \mathrm{~g}$ mandarin peel waste using popping pretreatment and enzyme hydrolysis supported by the S. cerevisiae KCTC 7906 strain. In summary (as reported in Table 3), the most recent bioethanol production studies focus on utilizing agriculture residues, where both SSF and SHF techniques are used to produce ethanol. Almost $84 \%$ of the studies cited used $S$. cerevisiae as a biocatalyst for fermentation. Table 3 shows that unripe banana peel (Prakash, Chauhan, General, \& Sharma, 2018; Waghmare \& Arya, 2016), Matooke peels (Yusuf \& Inambao, 2019a), Agave tequilana bagasse (Aguilar et al., 2018; Rios-González et al., 2017), banana peels (Tabasco variety) (Palacios et al., 2017), A. salmiana (Flores-Gómez et al., 2018), G. verrucosa (Sukwong et al., 2018), empty palm fruit bunch fiber (S. Kim, 2018), rice straw (Bahmani et al., 2016), switchgrass (Papa et al., 2015), and corn stover (Uppugundla et al., 2014) all have a high ethanol yield, and are suitable for commercial bioethanol production in different locations or regions. This classification of bioethanol fuel from different lignocellulosic materials and processes are currently being developed to meet sustainability and fuel quality standards, as well as the need for roads, aviation, and electricity. 
Bioethanol Production Techniques from Lignocellulosic Biomass as Alternative Fuel: A Review

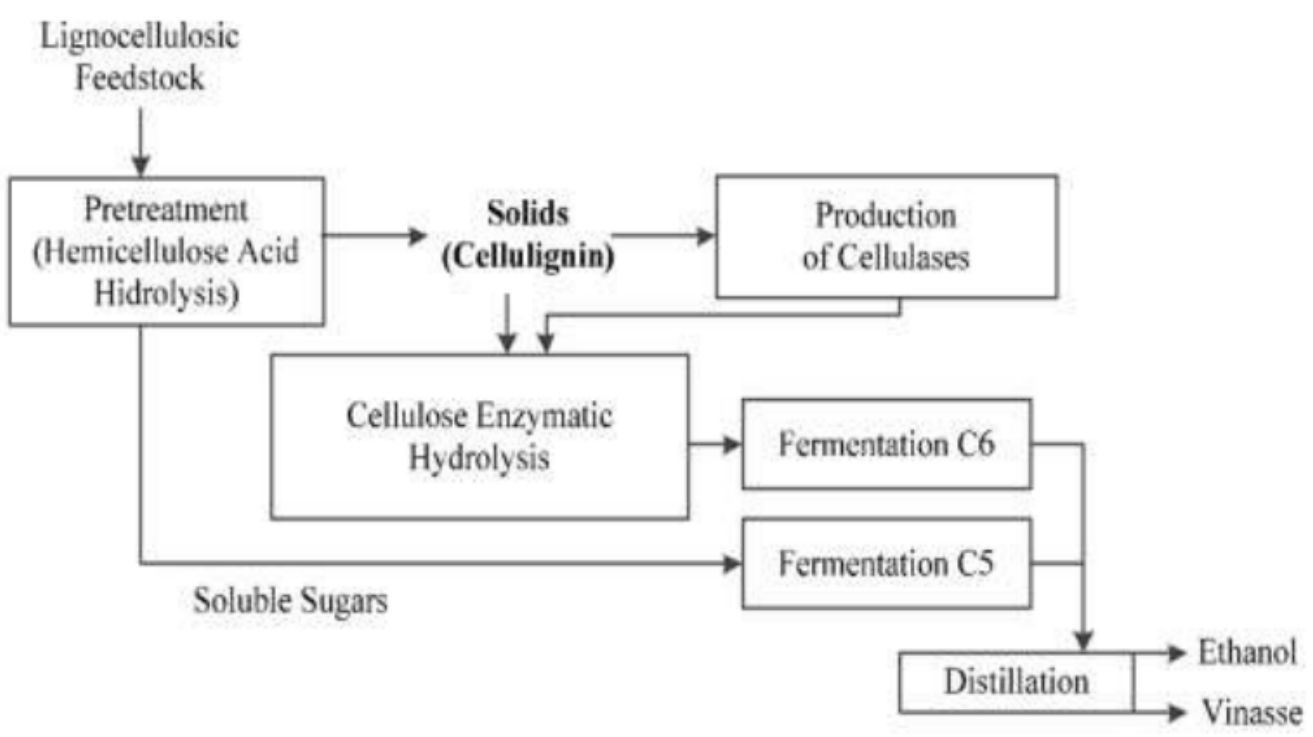

Figure 7 The schematic process of the separate hydrolysis and fermentation process (SHF) (Sebayang et al., 2016).

Table 2 Advantages and disadvantages of separate hydrolysis and fermentation (SHF), simultaneous saccharification and fermentation (SSF) and simultaneous saccharification and co-fermentation

(SSCF).

\begin{tabular}{|c|c|c|}
\hline Fermentation processes & Advantages & Disadvantages \\
\hline $\begin{array}{l}\text { Separate hydrolysis and } \\
\text { fermentation (SHF) }\end{array}$ & $\begin{array}{l}\text { Ability to carry out each step under } \\
\text { optimal conditions, i.e., enzymatic } \\
\text { hydrolysis at } 45^{\circ} \mathrm{C} \text { to } 50{ }^{\circ} \mathrm{C} \text { for } \\
\text { better performance and fermentation } \\
\text { at } 30^{\circ} \mathrm{C} \text { for optimizing sugar } \\
\text { utilization (Mohd Azhar et al., 2017; } \\
\text { Tengborg, Galbe, \& Zacchi, 2001). } \\
\text { SHF is more efficient than SSF } \\
\text { when bioethanol production is } \\
\text { carried out using cellulosic biomass } \\
\text { (Cotana et al., 2015; Wirawan, } \\
\text { Cheng, Kao, Lee, \& Chang, 2012). } \\
\text { The yeast produced during the SHF } \\
\text { process can be recycled after } \\
\text { fermentation of the hydrolysate, } \\
\text { which is not possible in SSF } \\
\text { (Olofsson, Bertilsson, \& Lidén, } \\
\text { 2008). }\end{array}$ & $\begin{array}{l}\text { Inhibition of cellulase and } \beta \text { - } \\
\text { glucosidase enzymes by } \\
\text { glucose released during } \\
\text { hydrolysis, which calls for } \\
\text { lower solids loadings and } \\
\text { higher enzyme loadings to } \\
\text { achieve reasonable yields } \\
\text { (Balat, 2011). }\end{array}$ \\
\hline $\begin{array}{l}\text { Simultaneous } \\
\text { saccharification and } \\
\text { fermentation (SSF) }\end{array}$ & $\begin{array}{l}\text { Lower enzyme requirements; higher } \\
\text { product yields; lower requirements } \\
\text { for sterile conditions since glucose } \\
\text { is removed immediately and } \\
\text { bioethanol is produced; shorter } \\
\text { process time; and less reactor } \\
\text { volume (Sun \& Cheng, 2002). }\end{array}$ & $\begin{array}{l}\text { The conditions of SSF are } \\
\text { more difficult to optimize } \\
\text { (Krishna, Reddy, \& } \\
\text { Chowdary, 2001). } \\
\text { During SSF the release of } \\
\text { sugar is not controlled, as all } \\
\text { the cellulase enzymes are }\end{array}$ \\
\hline
\end{tabular}




\begin{tabular}{|c|c|c|}
\hline Fermentation processes & Advantages & Disadvantages \\
\hline & $\begin{array}{l}\text { The immediate consumption of } \\
\text { sugars by the microorganism } \\
\text { produces low sugar concentrations } \\
\text { in the fermentor, which significantly } \\
\text { reduces enzyme inhibition compared } \\
\text { to SHF (Schell Mark F.; Tucker, } \\
\text { Melvin P., 1999). } \\
\text { This process is often effective when } \\
\text { combined with dilute acid or high } \\
\text { temperature hot-water pretreatment } \\
\text { (Balat, 2011). } \\
\text { Accept the mode of improvement } \\
\text { which combines the cellulase } \\
\text { enzymes and fermenting microbes } \\
\text { in one vessel to improve the } \\
\text { bioethanol production economics } \\
\text { (Y. Yu, Lou, \& Wu, 2008). }\end{array}$ & $\begin{array}{l}\text { added at once (Erdei, Frankó, } \\
\text { Galbe, \& Zacchi, 2012). }\end{array}$ \\
\hline $\begin{array}{l}\text { Simultaneous } \\
\text { saccharification and co- } \\
\text { fermentation (SSCF) }\end{array}$ & $\begin{array}{l}\text { Reduced capital costs (Wingren, } \\
\text { Galbe, \& Zacchi, 2003). } \\
\text { Continuous removal of end-products } \\
\text { of enzymatic hydrolysis that inhibit } \\
\text { cellulases or } \beta \text {-glucosidases } \\
\text { (Olofsson et al., 2008). } \\
\text { Higher ethanol productivity and } \\
\text { yield than separate hydrolysis and } \\
\text { fermentation (Alfani, Gallifuoco, } \\
\text { Saporosi, Spera, \& Cantarella, 2000; } \\
\text { Tomás-Pejó, Oliva, Ballesteros, \& } \\
\text { Olsson, 2008). } \\
\text { Maintains glucose at low levels } \\
\text { allowing efficient co-fermentation } \\
\text { of glucose and xylose (Öhgren et al., } \\
\text { 2006). }\end{array}$ & $\begin{array}{l}\text { At high water insoluble } \\
\text { solids (WIS) content, the } \\
\text { ethanol yield decreases due } \\
\text { to an increase in mass } \\
\text { transfer resistance and } \\
\text { inhibitors concentration } \\
\text { (Hoyer, Galbe, \& Zacchi, } \\
\text { 2009). }\end{array}$ \\
\hline
\end{tabular}

Table 3 Different methods, conditions and their effects for bioethanol from various biomasses (reported between the years 2013 to 2019).

\begin{tabular}{|c|c|c|c|c|c|c|c|}
\hline $\begin{array}{c}\text { Biomas } \\
\mathrm{s}\end{array}$ & $\begin{array}{c}\text { Pretreatm } \\
\text { ent } \\
\text { conditions }\end{array}$ & $\begin{array}{c}\text { Hydrolysi } \\
\text { s } \\
\text { conditions }\end{array}$ & Sugar yield & $\begin{array}{l}\text { Fermentatio } \\
\text { n conditions }\end{array}$ & \begin{tabular}{|c} 
Results: \\
Ethanol \\
yield \\
\end{tabular} & Remarks & Reference \\
\hline \multirow[t]{2}{*}{$\begin{array}{c}\text { Energy } \\
\text { grass }\end{array}$} & $\begin{array}{c}\text { Alkali: } 100 \\
\mathrm{ml} \text { of } 1 \% \\
(\mathrm{w} / \mathrm{v}) \\
\mathrm{NaOH} \text { at } \\
121^{\circ} \mathrm{C} \text { for } \\
1 \mathrm{~h} \\
\end{array}$ & \multirow{2}{*}{\begin{tabular}{|c} 
Enzymatic \\
hydrolysis \\
by Cellic $^{\circledR}$ \\
CTech \\
with 0.1 \\
$\mathrm{~g} / \mathrm{g}$ grass \\
at $50{ }^{\circ} \mathrm{C}$ \\
$150 \mathrm{rpm}$,
\end{tabular}} & $467.9 \mathrm{mg} / \mathrm{g}$ & - & - & \multirow{2}{*}{$\begin{array}{l}\text { Ozonolysis } \\
\text { is an } \\
\text { efficient } \\
\text { pretreatme } \\
\text { nt method } \\
\text { for energy } \\
\text { grasses, } \\
\text { resulting in }\end{array}$} & \multirow{2}{*}{$\begin{array}{l}\text { (Panneersel } \\
\text { vam, } \\
\text { Sharma- } \\
\text { Shivappa, } \\
\text { Kolar, } \\
\text { Clare, \& } \\
\text { Ranney, } \\
\text { 2013) }\end{array}$} \\
\hline & $\begin{array}{c}\text { Ozonolysis } \\
\text { : performed }\end{array}$ & & $431.9 \mathrm{mg} / \mathrm{g}$ & - & & & \\
\hline
\end{tabular}


Bioethanol Production Techniques from Lignocellulosic Biomass as Alternative Fuel: A Review

\begin{tabular}{|c|c|c|c|c|c|c|c|}
\hline $\begin{array}{c}\text { Biomas } \\
\mathrm{s}\end{array}$ & $\begin{array}{c}\text { Pretreatm } \\
\text { ent } \\
\text { conditions }\end{array}$ & $\begin{array}{c}\text { Hydrolysi } \\
\text { s } \\
\text { conditions }\end{array}$ & Sugar yield & $\begin{array}{l}\text { Fermentatio } \\
\text { n conditions }\end{array}$ & $\begin{array}{c}\text { Results: } \\
\text { Ethanol } \\
\text { yield }\end{array}$ & Remarks & Reference \\
\hline & $\begin{array}{l}\text { for } 2 \mathrm{~h} \text { at a } \\
\text { flow rate of } \\
0.25 \mathrm{l} / \mathrm{min} \\
\end{array}$ & $\begin{array}{c}\mathrm{pH} 4.8 \text { for } \\
72 \mathrm{~h}\end{array}$ & & & & $\begin{array}{c}\text { up to } 51 \% \\
\text { delignificat } \\
\text { ion. }\end{array}$ & \\
\hline \multirow{3}{*}{$\begin{array}{l}\text { Corn } \\
\text { stover }\end{array}$} & $\begin{array}{l}\text { DA: } \mathrm{H}_{2} \mathrm{SO}_{4} \\
\text { of } 5 \mathrm{CL} \\
\text { with } 895.5 \\
\mathrm{~kg} \text { of } \mathrm{H}_{2} \mathrm{O} \\
\text { at } 160^{\circ} \mathrm{C} \\
\text { for } 20 \mathrm{~min} \\
\text { and } \mathrm{N}-\mathrm{CR}\end{array}$ & $\begin{array}{c}\text { Biomass: } \\
29 \mathrm{~kg} \\
\text { glucan, } \\
\text { CTec2: } \\
583 \mathrm{~g}, \\
\mathrm{HTec} 2: \\
287 \mathrm{~g} \text { at } \\
50^{\circ} \mathrm{C} \text { with } \\
\mathrm{pH} 4.8 \text { for } \\
72 \mathrm{~h}\end{array}$ & $\begin{array}{c}65 \mathrm{~g} / \mathrm{L} \text { of } \\
\text { glucose }{ }^{\mathrm{a}} \text { and } 4 \\
\mathrm{~g} / \mathrm{L} \text { of } x y l o s e \\
\text { in } 72 \mathrm{~h}\end{array}$ & \multirow{3}{*}{$\begin{array}{c}\text { S. cerevisiae } \\
\text { strain } 424 \mathrm{~A} \\
\text { (LNH-ST), } \\
0.28 \mathrm{~g} \text { dry- } \\
\text { cell-wt./L } \\
\text { and operated } \\
\text { for } 120 \mathrm{~h} \\
(\mathrm{SSF})\end{array}$} & $14 \mathrm{~kg}$ & \multirow{3}{*}{$\begin{array}{c}\text { AFEX } \\
\text { produces } \\
\text { high } \\
\text { digestible } \\
\text { substrates, } \\
\text { high } \\
\text { fermentatio } \\
\text { n metabolic } \\
\text { yield with } \\
98 \% .\end{array}$} & \multirow{3}{*}{$\begin{array}{c}\text { (Uppugund } \\
\text { la et al., } \\
2014)\end{array}$} \\
\hline & $\begin{array}{c}\text { IL: } \\
{[\mathrm{C} 2 \mathrm{mim}][} \\
\text { OAc] of } \\
900 \mathrm{CL} \text { at } \\
140^{\circ} \mathrm{C} \text { for } \\
180 \mathrm{~min} \\
\text { and } \mathrm{CR}\end{array}$ & $\begin{array}{l}\text { Biomass: } \\
31.7 \mathrm{~kg} \\
\text { glucan, } \\
\text { CTec } 2: \\
371 \mathrm{~g}, \\
\mathrm{HTec} 2: \\
314 \mathrm{~g}, \\
\text { Multifect } \\
\text { Pectinase: } \\
266 \mathrm{~g} \text { at } \\
50^{\circ} \mathrm{C} \text { with } \\
\mathrm{pH} 4.8 \text { for } \\
72 \mathrm{~h}\end{array}$ & $\begin{array}{c}72 \mathrm{~g} / \mathrm{L} \text { of } \\
\text { glucose }^{\mathrm{b}} \text { and } \\
35 \mathrm{~g} / \mathrm{L} \text { of } \\
\text { xylose in } 72 \mathrm{~h}\end{array}$ & & $21.2 \mathrm{~kg}$ & & \\
\hline & $\begin{array}{c}\text { AFEX: } \\
\text { Anhydrous } \\
\text { ammonia } \\
\text { of } 100 \mathrm{CL} \\
\text { with } 60 \mathrm{~kg} \\
\text { of } \mathrm{H}_{2} \mathrm{O} \text { at } \\
140^{\circ} \mathrm{C}, \\
300 \text { psi for } \\
15 \text { min and } \\
\text { CR }\end{array}$ & $\begin{array}{l}\text { Biomass: } \\
33.5 \mathrm{~kg} \\
\text { glucan, } \\
\text { CTec } 2: \\
670 \mathrm{~g}, \\
\text { HTec } 2: \\
167.5 \mathrm{~g}, \\
\text { Multifect } \\
\text { Pectinase: } \\
167.5 \mathrm{~g} \text { at } \\
50^{\circ} \mathrm{C} \text { with } \\
\text { pH } 4.8 \text { for } \\
72 \mathrm{~h}\end{array}$ & $\begin{array}{c}60 \mathrm{~g} / \mathrm{L} \text { of } \\
\text { glucose } \mathrm{c}^{\mathrm{c}} \text { and } \\
29 \mathrm{~g} / \mathrm{L} \text { of } \\
\text { xylose in } 72 \mathrm{~h}\end{array}$ & & $20.5 \mathrm{~kg}$ & & \\
\hline $\begin{array}{c}\text { Sugarca } \\
\text { ne } \\
\text { bagasse }\end{array}$ & $\begin{array}{c}\text { Acid: } \\
\mathrm{H}_{2} \mathrm{SO}_{4} \text { of } 1 \\
\%(\mathrm{w} / \mathrm{v}) \\
1: 10 \text { solid- } \\
\text { liquid ratio }\end{array}$ & $\begin{array}{l}\text { Hydrolyze } \\
\mathrm{d} \text { by dilute } \\
\text { acid ( } 2.0 \\
\% \text { of } \\
\left.\mathrm{H}_{2} \mathrm{SO}_{4}\right) \text { at }\end{array}$ & $\begin{array}{l}\text { Glucose } 22.74 \\
\text { g/L, no xylose }\end{array}$ & $\begin{array}{l}\text { S. cerevisiae } \\
\text { stain NRRL } \\
\mathrm{Y}-7124 \text { at } 30 \\
{ }^{\circ} \mathrm{C}, 200 \mathrm{rpm} \\
\text { for } 72 \mathrm{~h}\end{array}$ & $\begin{array}{c}16.8 \mathrm{~g} / \mathrm{L} \\
\text { conc., } \\
0.38 \mathrm{~g} / \mathrm{g} \\
\text { and } 0.23 \\
\mathrm{~g} / \mathrm{L} / \mathrm{h}\end{array}$ & \begin{tabular}{|c|} 
This \\
process \\
generates \\
inhibitory \\
compounds \\
, and the
\end{tabular} & $\begin{array}{c}\text { (Bardone } \\
\text { et al., } \\
2014)\end{array}$ \\
\hline
\end{tabular}




\begin{tabular}{|c|c|c|c|c|c|c|c|}
\hline $\begin{array}{c}\text { Biomas } \\
\mathrm{s}\end{array}$ & $\begin{array}{c}\text { Pretreatm } \\
\text { ent } \\
\text { conditions }\end{array}$ & $\begin{array}{c}\text { Hydrolysi } \\
\text { s } \\
\text { conditions }\end{array}$ & Sugar yield & $\begin{array}{l}\text { Fermentatio } \\
\text { n conditions }\end{array}$ & \begin{tabular}{|c|} 
Results: \\
Ethanol \\
yield
\end{tabular} & Remarks & Reference \\
\hline & $\begin{array}{l}\text { at } 121^{\circ} \mathrm{C} \\
\text { for } 20 \mathrm{~min} \text {. }\end{array}$ & $\begin{array}{c}155^{\circ} \mathrm{C} \text { for } \\
10 \mathrm{~min}\end{array}$ & & & $\begin{array}{c}\text { productiv } \\
\text { ity }\end{array}$ & $\begin{array}{l}\text { detoxificati } \\
\text { on was } \\
\text { required } \\
\text { for } \\
\text { removing } \\
\text { those } \\
\text { compounds } \\
\text { found in } \\
\text { the } \\
\text { hydrolysate }\end{array}$ & \\
\hline $\begin{array}{l}\text { Switchg } \\
\text { rass }\end{array}$ & $\begin{array}{c}\text { IL: } \\
\text { Pretreated } \\
\text { with } \\
{[\mathrm{C} 2 \mathrm{C} 1 \mathrm{Im}][} \\
\text { OAc] at } \\
100^{\circ} \mathrm{C} \text { for } \\
3 \mathrm{~h}\end{array}$ & $\begin{array}{c}\text { Hydrolysis } \\
\text { by } \\
\text { cellulase } \\
\text { of } \\
\text { novozyme } \\
\text { HTec } 2 \text { at } \\
0.3 \% \mathrm{w} / \mathrm{w} \\
\text { (g } \\
\text { enzyme/g } \\
\text { xylan), } 30 \\
\text { min, } 2 \mathrm{~h}, 6 \\
\mathrm{~h}, 24 \mathrm{~h} \\
\text { and } 48 \mathrm{~h}\end{array}$ & $20 \mathrm{~g} / \mathrm{L}$ glucose & $\begin{array}{l}\text { S. cerevisiae } \\
\text { strain } \\
\mathrm{BY} 4741 \text { at } \\
30^{\circ} \mathrm{C}, 200 \\
\mathrm{rpm} \text { for } 20 \mathrm{~h}\end{array}$ & $85.7 \mathrm{~g}$ & $\begin{array}{c}\text { IL } \\
\text { pretreatme } \\
\text { nt } \\
\text { demonstrat } \\
\text { ed higher } \\
\text { bioethanol } \\
\text { yields. }\end{array}$ & $\begin{array}{c}\text { (Papa et } \\
\text { al., 2015) }\end{array}$ \\
\hline $\begin{array}{l}\text { Wheat } \\
\text { straw }\end{array}$ & $\begin{array}{l}\text { Ozonolysis } \\
\text { : Pretreated } \\
\text { for } 1 \text { and } 7 \\
\text { h at } 0.6 \\
1 / \text { min flow } \\
\text { rate with } \\
\text { ambient } \\
\text { conditions }\end{array}$ & \begin{tabular}{|} 
Enzymati \\
$\mathrm{c}$ \\
hydrolysis \\
was \\
performe \\
d for $72 \mathrm{~h}$
\end{tabular} & $\begin{array}{c}\text { Glucose of } 49 \\
\% \text { and xylose } \\
\text { of } 9.14 \%\end{array}$ & $\begin{array}{c}\text { (SSF) was } \\
\text { performed } \\
\text { for } 140 \mathrm{~h}\end{array}$ & $\begin{array}{c}12.9 \mathrm{~g} / \mathrm{L} \\
\text { and } 67 \% \\
\text { conc. }\end{array}$ & $\begin{array}{c}\text { Results } \\
\text { showed } \\
\text { that ozone } \\
\text { (or PAP) } \\
\text { not only } \\
\text { degraded } \\
\text { lignin but } \\
\text { also had an } \\
\text { effect on } \\
\text { epicuticula } \\
\text { r waxes on } \\
\text { wheat } \\
\text { straw. }\end{array}$ & $\begin{array}{l}\text { (Kádár et } \\
\text { al., 2015) }\end{array}$ \\
\hline $\begin{array}{l}\text { Rice } \\
\text { straw }\end{array}$ & $\begin{array}{c}\text { BP: } \\
\text { Pretreated } \\
\text { substrates } \\
\text { in } 30 \mathrm{~mL} \\
\text { of } 50 \mathrm{mM} \\
\text { sodium } \\
\text { citrate } \\
\text { buffer }(\mathrm{pH} \\
=4.8) \\
\end{array}$ & $\begin{array}{c}\text { Hydrolysis } \\
\text { was } \\
\text { conducted } \\
\text { using } 90 \\
\% \mathrm{v} / \mathrm{v} \\
\text { Cellic } \\
\text { CTec2 and } \\
10 \% \mathrm{v} / \mathrm{v} \\
\text { Cellic }^{\circledR}\end{array}$ & $\begin{array}{c}69.5 \% \text { of } \\
\text { hydrolysis } \\
\text { yield }\end{array}$ & $\begin{array}{l}\text { S. cerevisiae } \\
\text { (CCUG } \\
53310 \text { ) at } 37 \\
{ }^{\circ} \mathrm{C} \text { and } 130 \\
\mathrm{rpm} \text { for } 24 \mathrm{~h} \\
\text { through } \\
\text { (SHF) }\end{array}$ & $206 \mathrm{~g}$ & $\begin{array}{c}\text { Increasing } \\
\text { the } \\
\text { porosity of } \\
\text { the } \\
\text { substrate } \\
\text { by } \\
\text { hemicellul } \\
\text { ose } \\
\text { removal }\end{array}$ & $\begin{array}{c}\text { (Bahmani } \\
\text { et al., } \\
\text { 2016) }\end{array}$ \\
\hline
\end{tabular}


Bioethanol Production Techniques from Lignocellulosic Biomass as Alternative Fuel: A Review

\begin{tabular}{|c|c|c|c|c|c|c|c|}
\hline $\begin{array}{c}\text { Biomas } \\
\mathrm{s}\end{array}$ & $\begin{array}{c}\text { Pretreatm } \\
\text { ent } \\
\text { conditions }\end{array}$ & $\begin{array}{c}\text { Hydrolysi } \\
\text { s } \\
\text { conditions }\end{array}$ & Sugar yield & $\begin{array}{l}\text { Fermentatio } \\
\text { n conditions }\end{array}$ & \begin{tabular}{|c|} 
Results: \\
Ethanol \\
yield
\end{tabular} & Remarks & Reference \\
\hline & & $\begin{array}{c}\text { HTec2 and } \\
30 \text { FPU/g } \\
\text { cellulase } \\
\text { and } 50 \\
\text { IU/g } \beta- \\
\text { glucosidas } \\
\text { e at } 45^{\circ} \mathrm{C} \\
\text { and } 120 \\
\text { rpm for } 72 \\
\text { h. }\end{array}$ & & & & $\begin{array}{c}\text { could be } \\
\text { the main } \\
\text { effective } \\
\text { parameter } \\
\text { in this type } \\
\text { of } \\
\text { pretreatme } \\
\text { nt. } \\
\text { However, } \\
\text { enzymatic } \\
\text { hydrolysis } \\
\text { and ethanol } \\
\text { production } \\
\text { processes } \\
\text { need to be } \\
\text { improved. }\end{array}$ & \\
\hline $\begin{array}{c}\text { Banana } \\
\text { peels }\end{array}$ & \begin{tabular}{|} 
MP and \\
SE: \\
pretreated \\
with \\
autoclaved \\
at 15 psi \\
pressure \\
for 30 min, \\
knife \\
milling \\
with $2 \mathrm{~cm}$ \\
to $4 \mathrm{~cm}$ and \\
dried at 60 \\
${ }^{\circ} \mathrm{C}$ \\
\end{tabular} & $\begin{array}{c}0.5 \% \\
\text { (v/v) to } \\
2.5 \% \\
\text { (v/v) } \\
\text { diluted } \\
\text { sulfuric } \\
\text { acid } 70{ }^{\circ} \mathrm{C} \\
\text { and } 110 \\
{ }^{\circ} \mathrm{C}, \mathrm{pH} 7 \\
\text { for } 10 \mathrm{~min} \\
\text { to } 30 \mathrm{~min}\end{array}$ & $\begin{array}{c}11 \mathrm{~g} / \mathrm{L} \text { glucose } \\
\text { and } 5.5 \mathrm{~g} / \mathrm{L} \\
\text { xylose }\end{array}$ & $\begin{array}{c}\text { S. cerevisiae } \\
\text { strain at } 30 \\
{ }^{\circ} \mathrm{C}, 200 \mathrm{rpm} \\
\text { for } 24 \mathrm{~h}\end{array}$ & $\mid \begin{array}{c}45.088 \% \\
\text { of } \\
\text { bioethan } \\
\text { ol }\end{array}$ & $\begin{array}{l}\text { The waste } \\
\text { (banana } \\
\text { peels) from } \\
\text { the FPI } \\
\text { may bring } \\
\text { serious } \\
\text { environme } \\
\text { ntal } \\
\text { problems. } \\
\text { This can be } \\
\text { minimized } \\
\text { by the } \\
\text { production } \\
\text { of ethanol. }\end{array}$ & $\left(\begin{array}{c}\text { Gebregerg } \\
\text { s, } \\
\text { Gebresema } \\
\text { ti, \& Sahu, } \\
\text { 2016) }\end{array}\right.$ \\
\hline $\begin{array}{c}\text { Unripe } \\
\text { banana } \\
\text { peel }\end{array}$ & $\begin{array}{l}\text { MP: Dried } \\
\text { at } 60^{\circ} \mathrm{C} \text { for } \\
24 \mathrm{~h}, \\
\text { electric } \\
\text { grinder and } \\
\text { sieved } \\
\text { through } \\
\text { mesh } \\
\text { number } 36 \\
(0.45 \mathrm{~mm}) .\end{array}$ & $\begin{array}{c}\text { Hydrolyze } \\
\mathrm{d} \text { by } \\
\mathrm{H}_{2} \mathrm{SO}_{4} 1 \\
\%(\mathrm{v} / \mathrm{v}) \text { at } \\
120^{\circ} \mathrm{C}, \\
100 \mathrm{kPa} \\
\text { for } 10 \mathrm{~min}\end{array}$ & $\begin{array}{c}49.2 \%(\mathrm{w} / \mathrm{w}) \\
\text { of sugar } \\
\text { release }\end{array}$ & $\begin{array}{c}\text { S. cerevisiae } \\
\text { (NCIM } 3095 \text {, } \\
\text { NCIM } 3570 \\
\text { and NCIM } \\
3059) \text { at } 30 \\
{ }^{\circ} \mathrm{C} \text {, pH } 5, \\
150 \mathrm{rpm} \text { for } \\
36 \mathrm{~h}\end{array}$ & $\mid \begin{array}{c}35.5 \mathrm{~g} / \mathrm{L} \\
1.5 \mathrm{~g} / \mathrm{L} / \mathrm{h} \\
\text { productiv } \\
\text { ity }\end{array}$ & $\begin{array}{c}S . \\
\text { cerevisiae } \\
\text { NCIM } \\
3095 \text { was } \\
\text { found to be } \\
\text { the best } \\
\text { strain for } \\
\text { production } \\
\text { of ethanol } \\
\text { compared } \\
\text { to the other } \\
\text { two strains. }\end{array}$ & $\begin{array}{c}\text { (Waghmar } \\
\text { e \& Arya } \\
\text { 2016) }\end{array}$ \\
\hline $\begin{array}{c}\text { Elephan } \\
\text { t grass }\end{array}$ & $\begin{array}{l}\text { MP: Dried } \\
\text { at } 60{ }^{\circ} \mathrm{C} \text { for } \\
3 \text { days, } 4 \%\end{array}$ & \begin{tabular}{|c|}
124.43 \\
$\mathrm{U} / \mathrm{mL}$ \\
$6.16 \mathrm{U} / \mathrm{mL}$
\end{tabular} & $12.47 \mathrm{~g} / \mathrm{L}$ & $\begin{array}{l}\text { S. cerevisiae } \\
\mathrm{CAT}-1 \text { at } 28 \\
{ }^{\circ} \mathrm{C} \text { for } 48 \mathrm{~h}\end{array}$ & $6.1 \mathrm{~g} / \mathrm{L}$ & \begin{tabular}{|c|} 
High \\
ethanol \\
yield is not
\end{tabular} & \begin{tabular}{|c|} 
Menegol, \\
Fontana, \\
José,
\end{tabular} \\
\hline
\end{tabular}




\begin{tabular}{|c|c|c|c|c|c|c|c|}
\hline $\begin{array}{c}\text { Biomas } \\
\mathrm{s}\end{array}$ & $\begin{array}{c}\text { Pretreatm } \\
\text { ent } \\
\text { conditions }\end{array}$ & $\begin{array}{c}\text { Hydrolysi } \\
\text { s } \\
\text { conditions }\end{array}$ & Sugar yield & $\begin{array}{l}\text { Fermentatio } \\
\text { n conditions }\end{array}$ & $\begin{array}{c}\text { Results: } \\
\text { Ethanol } \\
\text { yield }\end{array}$ & Remarks & Reference \\
\hline & \begin{tabular}{|c|} 
to $20 \%$ \\
$(\mathrm{w} / \mathrm{v})$ in a \\
concomitan \\
t ball \\
milling \\
treatment / \\
triturated \\
with forage \\
chopper \\
$(0.5 \mathrm{~cm}$ to \\
$2 \mathrm{~cm})$.
\end{tabular} & \begin{tabular}{|c|} 
and \\
893.55 \\
$\mathrm{U} / \mathrm{ml}$ of b- \\
glucosidas \\
es, \\
endogluca \\
nases and \\
xylanases \\
at $50{ }^{\circ} \mathrm{C}$, \\
pH 4.8, \\
$150 \mathrm{rpm}$ \\
for $1 \mathrm{~h}$ to \\
$6 \mathrm{~h}$
\end{tabular} & & & & $\begin{array}{c}\text { only to do } \\
\text { with } \\
\text { biomass } \\
\text { but } \\
\text { depends on } \\
\text { enzymatic } \\
\text { and } \\
\text { fermentatio } \\
n \\
\text { processes. } \\
\text { There is a } \\
\text { need to } \\
\text { develop } \\
\text { equipment } \\
\text { for such } \\
\text { purposes. }\end{array}$ & \begin{tabular}{|c|} 
Dillon, \& \\
Camassola, \\
2016)
\end{tabular} \\
\hline $\begin{array}{l}\text { Pine } \\
\text { wood }\end{array}$ & $\begin{array}{c}\text { Alkali: } \\
\text { Performed } \\
\text { with } 0-2 \% \\
\text { w/v NaOH } \\
\text { at } 100-180 \\
{ }^{\circ} \mathrm{C} \text { for } 1 \mathrm{~h} \\
\text { to } 5 \mathrm{~h} .\end{array}$ & $\begin{array}{c}\text { Enzymes } \\
\text { mixture } \\
(90 \% \\
\text { Cellic }{ }^{\circledR} \\
\text { CTec } 2 \text { and } \\
10 \% \\
\text { Cellic }{ }^{\circledR} \\
\text { HTec2) at } \\
1.5 \mathrm{FPU} / \mathrm{g} \\
\text { substrate } \\
\text { of } \\
\text { cellulase } \\
\text { at } 45{ }^{\circ} \mathrm{C}, \\
\text { pH } 4.8, \\
120 \mathrm{rpm} \\
\text { for } 72 \mathrm{~h}\end{array}$ & $\begin{array}{c}83.5 \% \pm 0.3 \\
\% \text { glucose } \\
\text { yield }\end{array}$ & $\begin{array}{l}\text { S. cerevisiae } \\
\text { under } \\
\text { anaerobic } \\
\text { conditions } \\
\text { for } 24 \mathrm{~h}\end{array}$ & $\begin{array}{c}76.9 \% \\
\text { to } 78.0 \\
\% \text { and } \\
0.609 \\
\mathrm{~g} / \mathrm{L} / \mathrm{h} \pm \\
0.015 \\
\mathrm{~g} / \mathrm{L} / \mathrm{h} \\
\text { productiv } \\
\text { ity }\end{array}$ & $\begin{array}{c}\text { Production } \\
\text { of } \\
\text { bioethanol } \\
\text { requires } \\
\text { cheap raw } \\
\text { materials } \\
\text { which can } \\
\text { effectively } \\
\text { enhance } \\
\text { the } \\
\text { manufactur } \\
\text { ing costs. } \\
\text { Using } \\
\text { chemicals } \\
\text { for } \\
\text { neutralizati } \\
\text { on is } \\
\text { unavoidabl } \\
\text { e. }\end{array}$ & $\begin{array}{c}\text { (Safari, } \\
\text { Karimi, \& } \\
\text { Shafiei, } \\
\text { 2017) }\end{array}$ \\
\hline $\begin{array}{l}\text { Cotton } \\
\text { stalks }\end{array}$ & \begin{tabular}{|c|} 
Alkali: \\
$\mathrm{NaOH}(0.5$ \\
$\%$ to $4.0 \%$ \\
w/w $)$ and \\
the \\
biomass \\
loading $(10$ \\
$\%$ to $25 \%)$ \\
at $120{ }^{\circ} \mathrm{C}$ \\
for $20 \mathrm{~min}$
\end{tabular} & $\begin{array}{c}\text { Hydrolysis } \\
\text { by } \\
\text { cellulose } \\
\text { of } P . \\
\text { janthinellu } \\
m \text { and } 20 \\
\text { FPU/g } \\
\text { substrate } \\
\text { of } \\
\text { cellulose }\end{array}$ & $\begin{array}{c}25.59 \mathrm{~g} / \mathrm{L} \text { of } \\
\text { glucose and } \\
\text { hydrolytic } \\
\text { efficiency of } \\
80 \%\end{array}$ & $\begin{array}{c}4 \% \text { (wet } \\
\mathrm{wt} / \mathrm{v}) \mathrm{S} . \\
\text { cerevisiae } \\
\mathrm{RRP}-03 \mathrm{~N} \text { at } \\
30{ }^{\circ} \mathrm{C} \pm 2{ }^{\circ} \mathrm{C} \\
\text { for } 48 \mathrm{~h}, \\
(\mathrm{SHF})\end{array}$ & $9 \mathrm{~g}$ & \begin{tabular}{|c} 
Alkali \\
pretreatme \\
nt of cotton \\
stalks \\
effectively \\
de-lignified \\
the \\
biomass \\
and a \\
hydrolytic
\end{tabular} & $\begin{array}{c}\text { (Christoph } \\
\text { er, } \\
\text { Mathew, } \\
\text { Kiran } \\
\text { Kumar, } \\
\text { Pandey, \& } \\
\text { Sukumaran } \\
\text {, 2017) }\end{array}$ \\
\hline
\end{tabular}


Bioethanol Production Techniques from Lignocellulosic Biomass as Alternative Fuel: A Review

\begin{tabular}{|c|c|c|c|c|c|c|c|}
\hline $\begin{array}{c}\text { Biomas } \\
\mathrm{s}\end{array}$ & $\begin{array}{c}\text { Pretreatm } \\
\text { ent } \\
\text { conditions }\end{array}$ & $\begin{array}{c}\text { Hydrolysi } \\
\text { s } \\
\text { conditions }\end{array}$ & Sugar yield & $\begin{array}{l}\text { Fermentatio } \\
\text { n conditions }\end{array}$ & $\begin{array}{c}\text { Results: } \\
\text { Ethanol } \\
\text { yield } \\
\end{array}$ & Remarks & Reference \\
\hline & $\begin{array}{c}\text { Acid: } \\
\mathrm{H}_{2} \mathrm{SO}_{4}(0.5 \\
\% \text { to } 4.0 \% \\
\mathrm{w} / \mathrm{w}) \text { and } \\
\text { the } \\
\text { biomass } \\
\text { loading }(10 \\
\% \text { to } 25 \%) \\
\text { at } 120{ }^{\circ} \mathrm{C} \\
\text { for } 20 \mathrm{~min}\end{array}$ & $\begin{array}{l}\text { at } 50^{\circ} \mathrm{C}, \\
200 \mathrm{rpm} \\
\text { for } 48 \mathrm{~h}\end{array}$ & & & & \begin{tabular}{|c|} 
efficiency \\
of $80 \%$ \\
was \\
attained \\
with a \\
combinatio \\
n of \\
commercia \\
1 and in- \\
house \\
cellulases.
\end{tabular} & \\
\hline $\begin{array}{c}\text { Agave } \\
\text { tequilan } \\
a \\
\text { bagasse }\end{array}$ & $\begin{array}{c}\text { SE (AP): } \\
\text { Pretreated } \\
\text { at elevated } \\
\text { temperatur } \\
\text { es }\left(160{ }^{\circ} \mathrm{C}\right. \\
\left.\text { to } 240{ }^{\circ} \mathrm{C}\right) \\
\text { no } \\
\text { chemicals } \\
\text { required } \\
\text { but } \mathrm{H}_{2} \mathrm{O}\end{array}$ & $\begin{array}{l}\text { Hydrolyze } \\
\mathrm{d} \text { using } \\
\text { Cellic } \\
\text { CTec3 of } \\
25 \mathrm{FPU} / \mathrm{g} \\
\text { of glucan } \\
\text { at } 50^{\circ} \mathrm{C} \text {, } \\
\mathrm{pH} 4.8, \\
200 \mathrm{rpm} \\
\text { for } 72 \mathrm{~h}\end{array}$ & $\begin{array}{c}131 \mathrm{~g} / \mathrm{L} \pm 1.7 \\
\mathrm{~g} / \mathrm{L} \text { glucose } \\
\text { and } 81.5 \% \pm \\
1.7 \% \\
\text { hydrolysis }^{\text {ydeld }}\end{array}$ & $\begin{array}{l}\text { S. cerevisiae } \\
\text { ATCC } 4126 \\
\text { at } 30^{\circ} \mathrm{C}, \mathrm{pH} \\
5.5,100 \mathrm{rpm} \\
\text { for } 24 \mathrm{~h} \\
(\mathrm{SHF})\end{array}$ & $\begin{array}{c}65.26 \\
\mathrm{~g} / \mathrm{L} \text { and } \\
95 \% \text { of } \\
\text { the } \\
\text { theoretic } \\
\text { al value }\end{array}$ & \begin{tabular}{|} 
AP can be \\
an efficient \\
and \\
relatively \\
simple \\
method for \\
Agave \\
tequilana \\
that can be \\
incorporate \\
d in a $2^{\text {nd }}$ \\
GEPP.
\end{tabular} & \begin{tabular}{|} 
(Rios- \\
González \\
et al., \\
$2017)$
\end{tabular} \\
\hline $\begin{array}{c}\text { Banana } \\
\text { peels } \\
\text { (Tabasc } \\
o \\
\text { variety) }\end{array}$ & $\begin{array}{c}\text { Acid and } \\
\text { MP: } \mathrm{H}_{2} \mathrm{SO}_{4} \\
(0 \% \mathrm{v} / \mathrm{v}, \\
0.5 \% \mathrm{v} / \mathrm{v}, \\
1 \% \mathrm{v} / \mathrm{v}), \\
\text { autoclaved } \\
\text { at } 121{ }^{\circ} \mathrm{C}, \\
103 \mathrm{kPa} \text { for } \\
15 \mathrm{~min}, \\
\text { milled by } \\
\text { mechanical } \\
\text { grinding }(1 \\
\text { mm }) .\end{array}$ & $\begin{array}{c}15 \mathrm{FPU} / \mathrm{g} \\
\text { (Celluclast } \\
1.5 \mathrm{~L}) 10 \\
\%, 15 \% \\
\mathrm{w} / \mathrm{w}), \text { and } \\
20 \% \\
(\mathrm{w} / \mathrm{w}) \\
\text { pretreated } \\
\text { banana } \\
\text { peel }\end{array}$ & $32 \mathrm{~g} / \mathrm{L}$ glucose & $\begin{array}{l}\text { Kluyveromyc } \\
\text { es marxianus } \\
\text { at } 42^{\circ} \mathrm{C}, 150 \\
\text { rpm for } 24 \mathrm{~h}\end{array}$ & $21 \mathrm{~g} / \mathrm{L}$ & $\begin{array}{l}\text { The banana } \\
\text { peel } \\
\text { particle } \\
\text { size control } \\
\text { is not of } \\
\text { great } \\
\text { importance } \\
\text { for the } \\
\text { saccharific } \\
\text { ation of } \\
\text { this } \\
\text { lignocellul } \\
\text { osic } \\
\text { material. }\end{array}$ & $\begin{array}{l}(\text { Palacios et } \\
\text { al., 2017) }\end{array}$ \\
\hline $\begin{array}{c}A . \\
\text { tequilan } \\
a \\
\end{array}$ & \multirow{2}{*}{\begin{tabular}{|c|} 
AFEX: \\
$1000 \mathrm{~kg}$ \\
solid, \\
milling \\
DM, \\
Ammonia \\
$(2 \mathrm{~kg}$ \\
$\mathrm{NH3} / \mathrm{kg}$
\end{tabular}} & \multirow{2}{*}{$\begin{array}{c}\text { Cellic }^{\circledR} \\
\text { CTec3 and } \\
\text { HTec3 50 } \\
{ }^{\circ} \mathrm{C}, \mathrm{pH} \\
4.8,250 \\
\text { rpm, and } \\
72 \mathrm{~h}\end{array}$} & \begin{tabular}{|c|}
$252 \mathrm{~kg}$ glucose \\
and $109.8 \mathrm{~kg}$ \\
xylose
\end{tabular} & \multirow{2}{*}{\begin{tabular}{|} 
e Saccharomyc \\
es cerevisiae \\
$424 \mathrm{~A}$ \\
$(\mathrm{LNH}-\mathrm{ST})$ at \\
$30^{\circ} \mathrm{C}, 150$ \\
$\mathrm{rpm}, \mathrm{pH} 5.5$ \\
for $72 \mathrm{~h}$, \\
$(\mathrm{SHF})$
\end{tabular}} & $\begin{array}{r}154 \mathrm{~kg} \\
\text { ethanol }\end{array}$ & \multirow{2}{*}{\begin{tabular}{|c|} 
The \\
amount of \\
enzyme \\
loading \\
used in this \\
experiment \\
is higher; \\
identifying
\end{tabular}} & \multirow[b]{2}{*}{$\begin{array}{l}\text { (Flores- } \\
\text { Gómez et } \\
\text { al., 2018) }\end{array}$} \\
\hline $\begin{array}{c}A . \\
\text { salmian } \\
a\end{array}$ & & & $\begin{array}{c}301.4 \mathrm{~kg} \\
\text { glucose and } \\
107 \mathrm{~kg} \text { xylose }\end{array}$ & & $\begin{array}{l}176 \mathrm{~kg} \\
\text { ethanol }\end{array}$ & & \\
\hline
\end{tabular}




\begin{tabular}{|c|c|c|c|c|c|c|c|}
\hline $\begin{array}{c}\text { Biomas } \\
\mathrm{s}\end{array}$ & $\begin{array}{c}\text { Pretreatm } \\
\text { ent } \\
\text { conditions }\end{array}$ & $\begin{array}{c}\text { Hydrolysi } \\
\text { s } \\
\text { conditions }\end{array}$ & Sugar yield & $\begin{array}{l}\text { Fermentatio } \\
\text { n conditions }\end{array}$ & $\begin{array}{c}\text { Results: } \\
\text { Ethanol } \\
\text { yield }\end{array}$ & Remarks & Reference \\
\hline & $\begin{array}{l}\text { DM) with } \\
2 \mathrm{~kg} \text { of } \\
\mathrm{H} 2 \mathrm{O} \text { at } 102 \\
{ }^{\circ} \mathrm{C} \text { to } 120 \\
{ }^{\circ} \mathrm{C} \text { for } 30 \\
\text { min to } 38 \\
\text { min }\end{array}$ & & & & & $\begin{array}{c}\text { the right } \\
\text { combinatio } \\
n \text { of } \\
\text { accessory } \\
\text { enzymes in } \\
\text { the future } \\
\text { will further } \\
\text { reduce the } \\
\text { enzyme } \\
\text { loading. }\end{array}$ & \\
\hline $\begin{array}{l}\text { Agave } \\
\text { bagasse }\end{array}$ & $\begin{array}{l}\text { SE/HP } \\
\text { (AP): } \\
\text { performed } \\
\text { at } 180^{\circ} \mathrm{C} \\
\text { for } 20 \mathrm{~min} \text {, } \\
40 \mathrm{~min} \text {, } \\
\text { and } 50 \mathrm{~min}\end{array}$ & $\begin{array}{c}\text { Novozyme } \\
S \text { using } 20 \\
\text { FPU/g of a } \\
\text { substrate } \\
\text { as loading } \\
\text { of } \\
\text { cellulose } \\
\text { at } 150 \\
\text { rpm, pH } \\
4.8,180 \\
{ }^{\circ} \mathrm{C} \text { for } 20 \\
\text { min under } \\
\text { IR and } \\
\text { NIR }\end{array}$ & $\begin{array}{c}12.42 \mathrm{~g} / \mathrm{L} \\
\text { glucose at } 180 \\
{ }^{\circ} \mathrm{C}, 15.31 \mathrm{~g} / \mathrm{L} \\
\text { Xylooligosacc } \\
\text { harides and } \\
65.87 \% \text { of IR }\end{array}$ & \begin{tabular}{|} 
Saccharomyc \\
es cerevisiae \\
$\mathrm{PE}-2$ at 30 \\
${ }^{\circ} \mathrm{C}, 150 \mathrm{rpm}$ \\
for $12 \mathrm{~h}$ \\
under $(\mathrm{PSSF})$ \\
and $(\mathrm{SSSF})$
\end{tabular} & $\begin{array}{c}98.5 \%{ }^{\mathrm{f}}, \\
99.5 \% \mathrm{e}^{\mathrm{e}} \\
55.02 \\
\mathrm{~g} / \mathrm{L} \text { of } \\
\text { ethanol } \\
\text { concentr } \\
\text { ation and } \\
90.84 \% \\
\text { yield }\end{array}$ & $\begin{array}{c}\text { The result } \\
\text { showed a } \\
\text { decrease in } \\
\text { the ethanol } \\
\text { conc. on a } \\
\text { kinetic } \\
\text { profile, due } \\
\text { to ethanol } \\
\text { evaporatio } \\
\text { n during } \\
\text { the } \\
\text { production } \\
\text { process, } \\
\text { and the } \\
\text { SSSF } \\
\text { process } \\
\text { was } \\
\text { completed } \\
\text { after } 72 \mathrm{~h} .\end{array}$ & $\begin{array}{l}\text { (Aguilar et } \\
\text { al., 2018) }\end{array}$ \\
\hline $\begin{array}{c}G . \\
\text { verruco } \\
\text { sa }\end{array}$ & $\begin{array}{l}\text { Acid: } 12 \% \\
\text { (w/v) } G . \\
\text { verrucosa } \\
\text { with } 0.2 \mathrm{M} \\
\mathrm{H}_{2} \mathrm{SO}_{4} \text { at } \\
130^{\circ} \mathrm{C} \text { for } \\
15 \mathrm{~min}\end{array}$ & $\begin{array}{c}\text { Celluclast } \\
1.5 \mathrm{~L}, \\
\text { Viscozym } \\
\text { e L, and } \\
\text { Cellic } \\
\text { CTec } 2 \text { at } \\
50^{\circ} \mathrm{C}, 150 \\
\mathrm{rpm} \text { for } 48 \\
\mathrm{~h}\end{array}$ & $\begin{array}{c}50.7 \mathrm{~g} / \mathrm{L} \\
\text { monosaccharid } \\
\text { es }\end{array}$ & $\begin{array}{c}\text { Pichia } \\
\text { stipitis and } \\
\text { Kluyveromyc } \\
\text { es marxianus } \\
\text { at } 150 \mathrm{rpm} \text { at } \\
30^{\circ} \mathrm{C}\end{array}$ & $\begin{array}{c}29.0 \mathrm{~g} / \mathrm{L} \\
\text { ethanol, } \\
0.81 \\
\mathrm{~g} / \mathrm{L} / \mathrm{h} \\
\text { productiv } \\
\text { ity }\end{array}$ & $\begin{array}{c}\text { P. stipitis } \\
\text { showed } \\
\text { more } \\
\text { efficient } \\
\text { cell growth } \\
\text { and } \\
\text { bioethanol } \\
\text { productivit } \\
\text { y than } K . \\
\text { marxianus. }\end{array}$ & $\begin{array}{c}\text { (Sukwong } \\
\text { et al., } \\
2018)\end{array}$ \\
\hline $\begin{array}{c}\text { Banana } \\
\text { peels }\end{array}$ & $\begin{array}{c}\text { Acid: } \\
\text { pretreated } \\
\text { using HCl, } \\
\text { pH 5.0. }\end{array}$ & \begin{tabular}{|c|} 
Xylanase \\
1.99 \\
IUm/L, \\
FPase 2.0 \\
IU m/L, \\
pectinase \\
$4.0 \mathrm{IU}$ \\
\end{tabular} & $\begin{array}{l}37.06 \mathrm{mg} \mathrm{m} / \mathrm{L} \\
\mathrm{ORS} \text { at } 70^{\circ} \mathrm{C}\end{array}$ & \begin{tabular}{|} 
Geobacillus \\
stearothermo \\
philus strain \\
HPA19 at 37 \\
${ }^{\circ} \mathrm{C}$ for $30 \mathrm{~h}$
\end{tabular} & $\begin{array}{c}21.1 \mathrm{~g} / \mathrm{L}, \\
\text { eff. of } \\
76.5 \% \text { at } \\
30 \mathrm{~h}\end{array}$ & \begin{tabular}{|} 
It is good \\
to know \\
the suitable \\
ratio of \\
cellulolytic \\
and \\
hemicellul
\end{tabular} & $\begin{array}{l}\text { (Prakash et } \\
\text { al., 2018) }\end{array}$ \\
\hline
\end{tabular}


Bioethanol Production Techniques from Lignocellulosic Biomass as Alternative Fuel: A Review

\begin{tabular}{|c|c|c|c|c|c|c|c|}
\hline $\begin{array}{c}\text { Biomas } \\
\mathbf{s}\end{array}$ & $\begin{array}{c}\text { Pretreatm } \\
\text { ent } \\
\text { conditions }\end{array}$ & $\begin{array}{c}\text { Hydrolysi } \\
\text { s } \\
\text { conditions }\end{array}$ & Sugar yield & $\begin{array}{l}\text { Fermentatio } \\
\text { n conditions }\end{array}$ & $\begin{array}{c}\text { Results: } \\
\text { Ethanol } \\
\text { yield }\end{array}$ & Remarks & Reference \\
\hline & & \begin{tabular}{|c|}
$\mathrm{m} / \mathrm{L}$, \\
substrate \\
$(2.5 \%$ to \\
$20 \%)$ at \\
$\left(60^{\circ} \mathrm{C}\right.$ to \\
$\left.90^{\circ} \mathrm{C}\right), \mathrm{pH}$ \\
$9.0,150$ \\
$\mathrm{rpm}$ for $(1$ \\
$\mathrm{h}$ to $4 \mathrm{~h})$. \\
\end{tabular} & & & & \begin{tabular}{|c|} 
olytic \\
enzyme for \\
different \\
substrates \\
to produce \\
maximum \\
reduction \\
sugars. \\
\end{tabular} & \\
\hline $\begin{array}{c}\text { Orange } \\
\text { peel }\end{array}$ & $\begin{array}{l}\text { MP: milled } \\
\text { with a } \\
\text { grinding } \\
\text { machine } \\
\text { and dried }\end{array}$ & \begin{tabular}{|c|} 
Cellulase \\
1.06 \\
$\mathrm{U} / \mathrm{mL}$, \\
337.42 \\
$\mathrm{U} / \mathrm{mL}$, and \\
$1.36 \mathrm{U} / \mathrm{mL}$ \\
at $37^{\circ} \mathrm{C}$ \\
for $18 \mathrm{~h}$
\end{tabular} & $20 \mathrm{~g} / \mathrm{L}$ glucose & $\begin{array}{c}\text { S. cerevisiae } \\
\text { genome via } \\
\text { the CRISPR- } \\
\text { Cas9 } \\
\text { approach at } \\
30^{\circ} \mathrm{C}, 180 \\
\mathrm{rpm} \text { for } 60 \mathrm{~h} \\
\text { (SSF) }\end{array}$ & $7.53 \mathrm{~g} / \mathrm{L}$ & \begin{tabular}{|} 
The \\
engineered \\
strains may \\
provide a \\
valuable \\
material for \\
the \\
developme \\
nt of \\
lignocellul \\
osic \\
ethanol.
\end{tabular} & $\begin{array}{l}\text { (Yang et } \\
\text { al., 2018) }\end{array}$ \\
\hline \multirow{3}{*}{$\begin{array}{l}\text { Sunflow } \\
\text { er stalk }\end{array}$} & $\begin{array}{c}\text { IL: } \\
{[\mathrm{Bmim}] \mathrm{Cl}} \\
10 \% \text { to } 25 \\
\%(\mathrm{w} / \mathrm{w}) \\
\mathrm{pH} 5.0,60 \\
{ }^{\circ} \mathrm{C} \text { for } 24 \mathrm{~h} \\
\end{array}$ & \multirow{3}{*}{$\begin{array}{c}\text { cellulase } \\
20 \mathrm{FPU}, \\
\text { and } 400 \\
\mathrm{IU} \text { of } \\
\text { xylanase } / \mathrm{g} \\
\text { biomass at } \\
50^{\circ} \mathrm{C} \text { for } \\
72 \mathrm{~h}\end{array}$} & \multirow{3}{*}{$\begin{array}{c}302.4 \mathrm{mg} / \mathrm{g} \\
\text { glucose, } 107 \\
\text { mg xylose, } \\
114 \mathrm{mg} / \mathrm{g} \\
\text { reducing } \\
\text { sugars }\end{array}$} & \multirow{3}{*}{$\begin{array}{c}\text { P. oxalicum } \\
\text { PN8 (SSF) }\end{array}$} & \multirow{3}{*}{$\begin{array}{c}(0.078 \\
\mathrm{g} / \mathrm{g} \\
\text { biomass }) \\
\text { of } \\
\text { ethanol }\end{array}$} & \multirow{3}{*}{\begin{tabular}{|c|} 
Results \\
showed \\
that the \\
combined \\
IL and \\
alkali \\
pretreatme \\
nt causes \\
more \\
drastic \\
alterations \\
in the \\
biomass \\
ultrastructu \\
re as \\
compared \\
to IL alone \\
or alkali \\
pretreatme \\
nt.
\end{tabular}} & \multirow{3}{*}{$\begin{array}{l}\text { (Nargotra, } \\
\text { Sharma, } \\
\text { Gupta, } \\
\text { Kour, \& } \\
\text { Bajaj, } \\
\text { 2018) }\end{array}$} \\
\hline & \begin{tabular}{|c} 
Alkali: \\
$\mathrm{NaOH} 0.2$ \\
$\%$ to $2.0 \%$, \\
$(\mathrm{w} / \mathrm{v}), \mathrm{pH}$ \\
$5.0,60{ }^{\circ} \mathrm{C}$ \\
for $24 \mathrm{~h}$ \\
\end{tabular} & & & & & & \\
\hline & $\begin{array}{c}\text { IL and } \\
\text { Alkali: } \\
\mathrm{NaOH} 0.5 \\
\% \mathrm{w} / \mathrm{v} \text { and } \\
{[\mathrm{Bmim}] \mathrm{Cl}} \\
(25 \%, \\
\mathrm{w} / \mathrm{w}) 90^{\circ} \mathrm{C} \\
\text { for } 2 \mathrm{~h}\end{array}$ & & & & & & \\
\hline $\begin{array}{c}\text { Empty } \\
\text { palm } \\
\text { fruit }\end{array}$ & $\begin{array}{l}\text { Alkali- } \\
\text { thermal: } \\
\text { NaOH, } \\
\text { dried }\end{array}$ & $\begin{array}{c}\text { (Celluclast } \\
1.5 \mathrm{~L}), 20 \\
\text { FPU to } \\
100 \mathrm{FPU}\end{array}$ & $\begin{array}{c}82.2 \% \\
\text { fermentable } \\
\text { sugar } \\
\text { conversion }\end{array}$ & $\begin{array}{c}\text { S. cerevisiae } \\
\mathrm{W} 303-1 \mathrm{~A} \\
\text { strain at } 30 \\
{ }^{\circ} \mathrm{C}, 200 \mathrm{rpm}\end{array}$ & $\begin{array}{c}33.8 \pm 0.5 \\
\mathrm{~g} / \mathrm{L} \\
\text { ethanol } \\
\text { with } 1.57\end{array}$ & $\begin{array}{c}\text { Separate } \\
\text { hydrolysis } \\
\text { and } \\
\text { fermentatio }\end{array}$ & $\begin{array}{c}\text { (S. Kim, } \\
2018)\end{array}$ \\
\hline
\end{tabular}




\begin{tabular}{|c|c|c|c|c|c|c|c|}
\hline $\begin{array}{c}\text { Biomas } \\
\mathrm{s}\end{array}$ & $\begin{array}{c}\text { Pretreatm } \\
\text { ent } \\
\text { conditions }\end{array}$ & $\begin{array}{c}\text { Hydrolysi } \\
\text { s } \\
\text { conditions }\end{array}$ & Sugar yield & $\begin{array}{l}\text { Fermentatio } \\
\text { n conditions }\end{array}$ & $\begin{array}{c}\text { Results: } \\
\text { Ethanol } \\
\text { yield }\end{array}$ & Remarks & Reference \\
\hline $\begin{array}{l}\text { bunch } \\
\text { fiber }\end{array}$ & $\begin{array}{c}\text { sample }(20 \\
\% \mathrm{w} / \mathrm{v}) \text { at } \\
105^{\circ} \mathrm{C} \text { for } \\
24 \mathrm{~h}, \\
\text { autoclave } \\
\left(121^{\circ} \mathrm{C}, 15\right. \\
\mathrm{psi}, 60 \\
\mathrm{~min})\end{array}$ & $\begin{array}{c}\text { and } \beta- \\
\text { glucosidas } \\
\text { e } \\
\text { (Novozym } \\
\text { e 188; } 40 \\
\text { CBU) for } \\
72 \mathrm{~h}\end{array}$ & & $\begin{array}{l}\text { for } 28 \mathrm{~h}, \\
\text { (SHF) }\end{array}$ & $\begin{array}{c}\mathrm{g} / \mathrm{L} / \mathrm{h} \\
\text { productiv } \\
\text { ity }\end{array}$ & $\begin{array}{c}\mathrm{n} \text { using } \\
\mathrm{v} \text { ydrolysate } \\
\text { are useful } \\
\text { for } \\
\text { producing } \\
\text { bioethanol } \\
\text { with high } \\
\text { productivit } \\
\text { y. }\end{array}$ & \\
\hline $\begin{array}{l}\text { Matook } \\
e \text { peels }\end{array}$ & $\begin{array}{l}\text { MP: Dried } \\
\text { at } 58{ }^{\circ} \mathrm{C} \text { for } \\
83 \mathrm{~h}, 0.2 \\
\mathrm{~mm} \text { to } 2 \\
\text { mm after } \\
\text { milling and } \\
\text { grinding } \\
\text { with an } \\
\text { electric } \\
\text { grinder }\end{array}$ & $\begin{array}{c}0.5 \% \\
\text { (v/v) to } \\
2.5 \% \\
(\mathrm{v} / \mathrm{v}) \text { of } \\
\mathrm{H}_{2} \mathrm{SO}_{4}, 50 \\
{ }^{\circ} \mathrm{C} \text { to } 90 \\
{ }^{\circ} \mathrm{C} \pm 1{ }^{\circ} \mathrm{C} \\
\text { at } 20 \mathrm{~min} \\
\text { to } 60 \mathrm{~min} \\
\text { with } \\
\text { gentle } \\
\text { shaking }\end{array}$ & $\begin{array}{c}77.03 \mathrm{~g} / \mathrm{L} \\
\text { reducing } \\
\text { sugars }\end{array}$ & $\begin{array}{l}\text { S. cerevisiae } \\
\text { NCIM } 3570 \text {, } \\
\text { at } 29^{\circ} \mathrm{C} \text { to } \\
39^{\circ} \mathrm{C} \pm 1{ }^{\circ} \mathrm{C} \\
165 \mathrm{rpm}, \mathrm{pH} \\
5.0 \text { for about } \\
10 \mathrm{~h} \text { to } 30 \mathrm{~h}\end{array}$ & $\begin{array}{c}71.54 \\
\mathrm{~g} / \mathrm{L}\end{array}$ & \begin{tabular}{|c|} 
Utilizing \\
this waste \\
biomass for \\
bioethanol \\
production \\
through a \\
biotechnol \\
ogical \\
process not \\
only helps \\
to reduce \\
environme \\
ntal \\
pollution \\
but also \\
reduces \\
dependenc \\
e on oil- \\
producing \\
countries.
\end{tabular} & $\begin{array}{c}\text { (Yusuf \& } \\
\text { Inambao, } \\
\text { 2019a) }\end{array}$ \\
\hline
\end{tabular}

NOTE: ${ }^{\mathrm{a}}$ (88 \% glucan conversion), ${ }^{\mathrm{b}}$ (100\% glucan conversion), ${ }^{\mathrm{c}}$ (79\% glucan conversion), ${ }^{\mathrm{d}}$ (at severity factor of 4.43), ${ }^{\mathrm{e}}$ (at high-solids loading), ${ }^{\mathrm{f}}$ (Saccharification yields), $2^{\text {nd }}$ GEPP: Second generation ethanol production process, $[\mathrm{Bmim}] \mathrm{Cl}$ : 1-butyl-3-methyl imidazolium chloride, [C2C1 Im] [OAc]: 1-ethyl-3-methylimidazolium, [C2mim][OAc]: 1ethyl-3-methylimidazolium acetate, AbC: Aerobic condition, AFEX: Ammonia fiber expansion, BP: Biological pretreatment, CL: Catalyst loading of $\mathrm{kg} / 100 \mathrm{~kg}$ dry biomass, CR: Catalyst recycled, DA: Dilute acid, DM: Dry materials, FPI: Food processing industry, FPU: Filter paper units, HP (AP): Hydrothermal processing (autohydrolysis process), IL: Ionic liquid, IR: isothermal regime, ORS: Optimum reducing sugar, MP: Mechanical pretreatement, NIR: non-isothermal regime, N-CR: No catalyst recycled, PAP: Plasma assisted pretreatment, SHF: Separate hydrolysis and fermentation, SSF: Simultaneous saccharification and fermentation.

\section{BIOETHANOL AS ALTERNATIVE FUEL}

The most common agricultural residues utilized for bioethanol production have been discussed in the previous sections. The classification of bioethanol fuel from different lignocellulosic materials and processes are currently being developed to meet sustainability and fuel quality standards, as well as the need for roads, aviation, and electricity. The processes of pretreatment, 
hydrolysis, and fermentation have significant effects on physico-chemical properties of bioethanol fuel, which also affect the internal combustion engines. The small changes in physico-chemical properties on bioethanol fuels are enough to create a significant change in the combustion system and sometimes make it difficult to analyze the fundamental of how it affects $\mathrm{CO}, \mathrm{CO}_{2}, \mathrm{HC}, \mathrm{NO}_{\mathrm{x}}$ and $\mathrm{PM}$ emissions. That means not all bioethanol fuel bring benefits to the environment concerning the emissions and performance. In the literature, the use of bioethanol as fuel goes back to the origin of the use of motorized vehicles. For example, Henry Ford's Model T, built in 1908, ran on bioethanol (Walter \& Segerstedt, 2012). Interest waned in the following decades due to the environmental issue of reducing greenhouse gas, rising vehicle fuel demand, and the security of energy supply sustain the development of bioethanol production from renewable resources (Berhane, 2016; Purwadi, 2006; Yusuf \& Inambao, 2019b)

Current research is focusing on how to blend bioethanol with gasoline or other additives under different ratios (Yusuf \& Inambao, 2018) to take advantage of bioethanol high octane number and low cetane number, which increases thermal efficiency and compression ratios of the engine compared to gasoline alone (H. Zhao et al., 2011). Bioethanol provides additional oxygen in combustion; when blended with gasoline its burns relatively more completely, therefore emitting lower $\mathrm{CO}$ and $\mathrm{HC}$ emissions compared to pure gasoline (E0) (S. Liu, Cuty Clemente, Hu, \& Wei, 2007; H. Zhao et al., 2011). The lower boiling point of bioethanol also helps to obtain better combustion efficiency (Hu, Wei, Liu, \& Zhou, 2007). However, it has lower energy density than gasoline and lower vapor pressure (Balat, Balat, \& Öz, 2008), and parts with lightweight design products directly influence the fuel consumption (Abdu, Shafii, Dubey, \& Gupta, 2016). The properties of any fuel depend on it is a chemical composition which determines the performance and emission characteristics of the engine. The properties of ethanol and gasoline are similar (as reported in Table 4).

Table 4 The physico-chemical properties of ethanol and gasoline

\begin{tabular}{|c|c|c|c|c|c|}
\hline Properties & Units & Test Methods & Ethanol & Gasoline & References \\
\hline Molecular formula & - & - & $\mathrm{C}_{2} \mathrm{H}_{5} \mathrm{OH}$ & $\mathrm{C}_{4}-\mathrm{C}_{12}$ & \\
\hline Composition $(\mathrm{C}, \mathrm{H}, \mathrm{O})$ & (Mass \%) & \begin{tabular}{|c|} 
ASTM D5291- \\
02
\end{tabular} & $52,13,35$ & $86,14,0$ & (Mohebbi et al., 2018) \\
\hline Density at $15^{\circ} \mathrm{C}$ & $(\mathrm{Kg} / \mathrm{L})$ & ISO 12185 & 0.79 & 0.73 & $\begin{array}{c}\text { (S. H. Park, Yoon, \& } \\
\text { Lee, 2014) }\end{array}$ \\
\hline Boiling point & $\left({ }^{\circ} \mathrm{C}\right)$ & - & 78.3 & 27 to 225 & $\begin{array}{c}\text { (Hedfi, Jedli, Jbara, \& } \\
\text { Slimi, 2014) }\end{array}$ \\
\hline $\begin{array}{c}\text { Auto-ignition } \\
\text { temperature }\end{array}$ & $\left({ }^{\circ} \mathrm{C}\right)$ & - & 360 & 228 to 470 & $\begin{array}{r}\text { (Balki, Sayin, \& } \\
\text { Canakci, 2014) } \\
\end{array}$ \\
\hline Flash point & $\left({ }^{\circ} \mathrm{C}\right)$ & ASTM D93 & 21.1 & -45 to -38 & (H. Liu et al., 2014) \\
\hline Lower hearting value & $(\mathrm{MJ} / \mathrm{kg})$ & ASTM D240 & 27.0 & 43.5 & (Elfasakhany, 2016) \\
\hline Octane number & VM & ASTM D2699 & 108 & 95 & $\begin{array}{c}\text { (Mařík, Pexa, Kotek, \& } \\
\text { Hönig, 2014) }\end{array}$ \\
\hline Cetane number & - & ASTM D2700 & 11 & 0 to 10 & $\begin{array}{l}\text { (Rajesh Kumar \& } \\
\text { Saravanan, 2016) }\end{array}$ \\
\hline $\begin{array}{l}\text { Latent heat of } \\
\text { vaporization }\end{array}$ & $(\mathrm{KJ} / \mathrm{kg})$ & - & 838 & 223.2 & (Thangavel et al., 2016) \\
\hline $\begin{array}{l}\text { Stoichiometric air/fuel } \\
\text { ratio }\end{array}$ & $\mathrm{w} / \mathrm{w}$ & - & 9.0 & 14.7 & (Gu et al., 2012) \\
\hline Viscosity at $20^{\circ} \mathrm{C}$ & $\left(\mathrm{mm}^{2} / \mathrm{s}\right)$ & - & 1.19 & 0.37 to 0.44 & $\begin{array}{l}\text { (Mohebbi et al., 2018; } \\
\text { Yücesu, Topgül, Çinar, } \\
\text { \& Okur, 2006) }\end{array}$ \\
\hline
\end{tabular}


Abdulfatah Abdu Yusuf and Freddie L. Inambao

\begin{tabular}{|c|c|c|c|c|c|}
\hline $\begin{array}{c}\text { Saturation pressure at } 38 \\
{ }^{\circ} \mathrm{C}\end{array}$ & $(\mathrm{KPa})$ & - & 13.8 & 31 & (Thangavel et al., 2016) \\
\hline $\begin{array}{c}\text { Flammability Limit, 20 } \\
{ }^{\circ} \mathrm{C}\end{array}$ & $(\mathrm{vol} \%)$ & - & 3.3 to 19 & 1.0 to 8.0 & $\begin{array}{c}\text { (Ulrik, Troels, \& } \\
\text { Jesper, 2009) }\end{array}$ \\
\hline Aromatics & $(\% \mathrm{v} / \mathrm{v})$ & - & 0 & 33.3 & $\begin{array}{c}\text { (Costagliola et al., } \\
\text { 2016) }\end{array}$ \\
\hline $\begin{array}{c}\text { Enthalpy of formation } \\
\text { Liquid } \\
\text { Gas }\end{array}$ & $\mathbf{( k J / m o l )}$ & - & -224.1 & -259.28 & (Masum et al., 2013) \\
\cline { 4 - 5 } & & -234.6 & -277 & \\
\hline
\end{tabular}

\section{CONCLUSION}

Bioethanol is an alternative fuel obtained from biomass and has been used in several countries for several years as it is considered to be renewable and clean energy. But not all bioethanol fuels bring benefits to the environment concerning the performance and emissions. Assessment needs to be made for each type of biomass material, location, and the extraction techniques.

According to the reviewed literature, both physical and biological processes are not cost competitive compared to the other pretreatments, but biological pretreatments are less harmful to the environment and can be performed in milder conditions, and thus are energy efficient compared to chemical and physico-chemical pretreatments. However, it is not possible to choose only one pretreatment as the best, because of the heterogeneity of the lignocellulose. The choice will depend on the nature or source of the lignocellulosic which needs to be treated, as well as on the use of the hydrolysate material. Fermentation processes have exhibited significant effects on bioethanol production. The SSF method has shown its ability to produce high ethanol concentrations with high productivity.

The processes of pretreatment, hydrolysis, and fermentation have significant effects on physico-chemical properties of bioethanol fuel, which also influence the internal combustion engines. The small changes in physico-chemical properties on bioethanol fuels are enough to create a significant change in the combustion system and sometimes make it difficult to analyze the fundamental of how it affects emissions.

\section{ACKNOWLEDGMENT}

The author gratefully acknowledges the financial support provided by Professor Freddie L. Inambao from Department of Mechanical Engineering, University of KwaZulu-Natal, Durban - South Africa and (DAAD) grant no: 91712001.

\section{REFERENCES}

[1] Abdu, Y. A., Shafii, T. M., Dubey, K. K., \& Gupta, U. K, Design and Analysis of Pressure Die Casting Die for Automobile Component. Global Journal of Research In Engineering, 16(1), 2016, pp 1-8.

[2] Aditiya, H. B., Chong, W. T., Mahlia, T. M. I., Sebayang, A. H., Berawi, M. A., \& Nur, H, Second generation bioethanol potential from selected Malaysia's biodiversity biomasses: A review. Waste Management, 2016

[3] Agbor, V. B., Cicek, N., Sparling, R., Berlin, A., \& Levin, D. B, Biomass pretreatment: Fundamentals toward application. Biotechnology Advances, 2011,

[4] Agudelo, R. A., García-Aparicio, M. P., \& Görgens, J. F, Steam explosion pretreatment of triticale $(\times$ Triticosecale Wittmack) straw for sugar production. New Biotechnology, 33, 2016, pp 153-163. https://doi.org/10.1016/j.nbt.2015.10.001

[5] Aguilar, D. L., Rodríguez-Jasso, R. M., Zanuso, E., de Rodríguez, D. J., Amaya-Delgado, L., Sanchez, A., \& Ruiz, H. A, Scale-up and evaluation of hydrothermal pretreatment in 
isothermal and non-isothermal regimen for bioethanol production using agave bagasse. Bioresource Technology, 263, 2018, 112-119.

[6] Alfani, F., Gallifuoco, A., Saporosi, A., Spera, A., \& Cantarella, M, Comparison of SHF and SSF processes for the bioconversion of steam-explode wheat straw. Journal of Industrial Microbiology and Biotechnology, 25, 2000, 184-192.

[7] Alizadeh, H., Teymouri, F., Gilbert, T. I., \& Dale, B. E, Pretreatment of switchgrass by ammonia fiber explosion (AFEX). In Applied Biochemistry and Biotechnology - Part A Enzyme Engineering and Biotechnology 2005, (pp. 1133-1141).

[8] Alvira, P., Tomás-Pejó, E., Ballesteros, M., \& Negro, M. J, Pretreatment technologies for an efficient bioethanol production process based on enzymatic hydrolysis: A review. Bioresource Technology, 101(13), 2010, 4851-4861.

[9] Amin, F. R., Khalid, H., Zhang, H., Rahman, S., Zhang, R., Liu, G., \& Chen, C, Pretreatment methods of lignocellulosic biomass for anaerobic digestion. AMB Express, 2017, https://doi.org/10.1186/s13568-017-0375-4

[10] Arumugam, R., \& Manikandan, M, Fermentation of pretreated hydrolyzates of banana and mango fruit wastes for ethanol production. Asian Journal of Experimental Biological Science, 2, 2011, 246-256.

[11] Bahmani, M. A., Shafiei, M., \& Karimi, K, Anaerobic digestion as a pretreatment to enhance ethanol yield from lignocelluloses. Process Biochemistry, 51, 2016, pp 1256-1263. https://doi.org/10.1016/j.procbio.2016.05.012

[12] Balat, M, Production of bioethanol from lignocellulosic materials via the biochemical pathway: A review. Energy Conversion and Management, 2011

[13] Balat, M., Balat, H., \& Öz, C, Progress in bioethanol processing. Progress in Energy and Combustion Science, 2008, https://doi.org/10.1016/j.pecs.2007.11.001

[14] Bali, G., Meng, X., Deneff, J. I., Sun, Q., \& Ragauskas, A. J, The effect of alkaline pretreatment methods on cellulose structure and accessibility. ChemSusChem, 8(2), 2015, pp 275-279. https://doi.org/10.1002/cssc.201402752

[15] Balki, M. K., Sayin, C., \& Canakci, M, The effect of different alcohol fuels on the performance, emission and combustion characteristics of a gasoline engine. Fuel, 115, 2014, 901-906. https://doi.org/10.1016/j.fuel.2012.09.020

[16] Bals, B., Rogers, C., Jin, M., Balan, V., \& Dale, B, Evaluation of ammonia fibre expansion (AFEX) pretreatment for enzymatic hydrolysis of switchgrass harvested in different seasons and locations. Biotechnology for Biofuels, 3, 2010, pp 1-11. https://doi.org/10.1186/17546834-3-1

[17] Bioprocessing, J. D. M., Fuels, A., \& Energy, R, Pretreatment of Lignocellulosic Biomass. ACS Publication, 15, 1994, pp 292-324.

[18] M. Ramarao and S. Vivekanandan, Evaluation of Carbon Conversion Efficiency of Mixed Biomass Gasification. International Journal of Mechanical Engineering and Technology, 7(6), 2016, pp. 555-564.

[19] Manish Kumar, Bireswar Paul and Dhananjay Singh Yadav, Effect of Moisture Content and Equivalence Ratio on the Gasification Process for Different Biomass Fuel. International Journal of Mechanical Engineering and Technology, 7(6), 2016, pp. 209-220.

[20] Bjerre, A. B., Olesen, A. B., Fernqvist, T., Plöger, A., \& Schmidt, A. S, Pretreatment of wheat straw using combined wet oxidation and alkaline hydrolysis resulting in convertible cellulose and hemicellulose. Biotechnology and Bioengineering, 49, 1996, 568-577.

[21] Boluda-Aguilar, M., García-Vidal, L., González-Castañeda, F. d P., \& López-Gómez, A., Mandarin peel wastes pretreatment with steam explosion for bioethanol production. Bioresource Technology, 101, 2010, pp 3506-3513.

[22] Bonner, I. J., Thompson, D. N., Plummer, M., Dee, M., Tumuluru, J. S., Pace, D., ... Bals, $\mathrm{B}$, Impact of ammonia fiber expansion (AFEX) pretreatment on energy consumption during 
drying, grinding, and pelletization of corn stover. Drying Technology, 34(11), 2016, pp 1319-1329. https://doi.org/10.1080/07373937.2015.1112809

[23] Calam, A., Içingür, Y., Solmaz, H., \& Yamk, H, A comparison of engine performance and the emission of fusel oil and gasoline mixtures at different ignition timings. International Journal of Green Energy, 12(8), 2015, pp 767-772.

[24] Chamy, R., Illanes, A., Aroca, G., \& Nuñez, L, Acid hydrolysis of sugar beet pulp as pretreatment for fermentation. Bioresource Technology, 50, 1994, pp 149-152. https://doi.org/10.1016/0960-8524(94)90067-1

[25] Chandel, A. K., Chandrasekhar, G., Radhika, K., \& Ravinder, R, Bioconversion of pentose sugars into ethanol: A review and future directions. Biotechnology and Molecular Biology, 6, 2011, pp 8-20. https://doi.org/ISSN 1538-2273

[26] Choi, I. S., Kim, J. H., Wi, S. G., Kim, K. H., \& Bae, H. J, Bioethanol production from mandarin (Citrus unshiu) peel waste using popping pretreatment. Applied Energy, 102, 2013, pp 204-10. https://doi.org/10.1016/j.apenergy.2012.03.066

[27] Costagliola, M. A., Prati, M. V., Florio, S., Scorletti, P., Terna, D., Iodice, P, Senatore, A, Performances and emissions of a 4-stroke motorcycle fuelled with ethanol/gasoline blends. Fuel, 183, 2016, pp 470-477. https://doi.org/10.1016/j.fuel.2016.06.105 